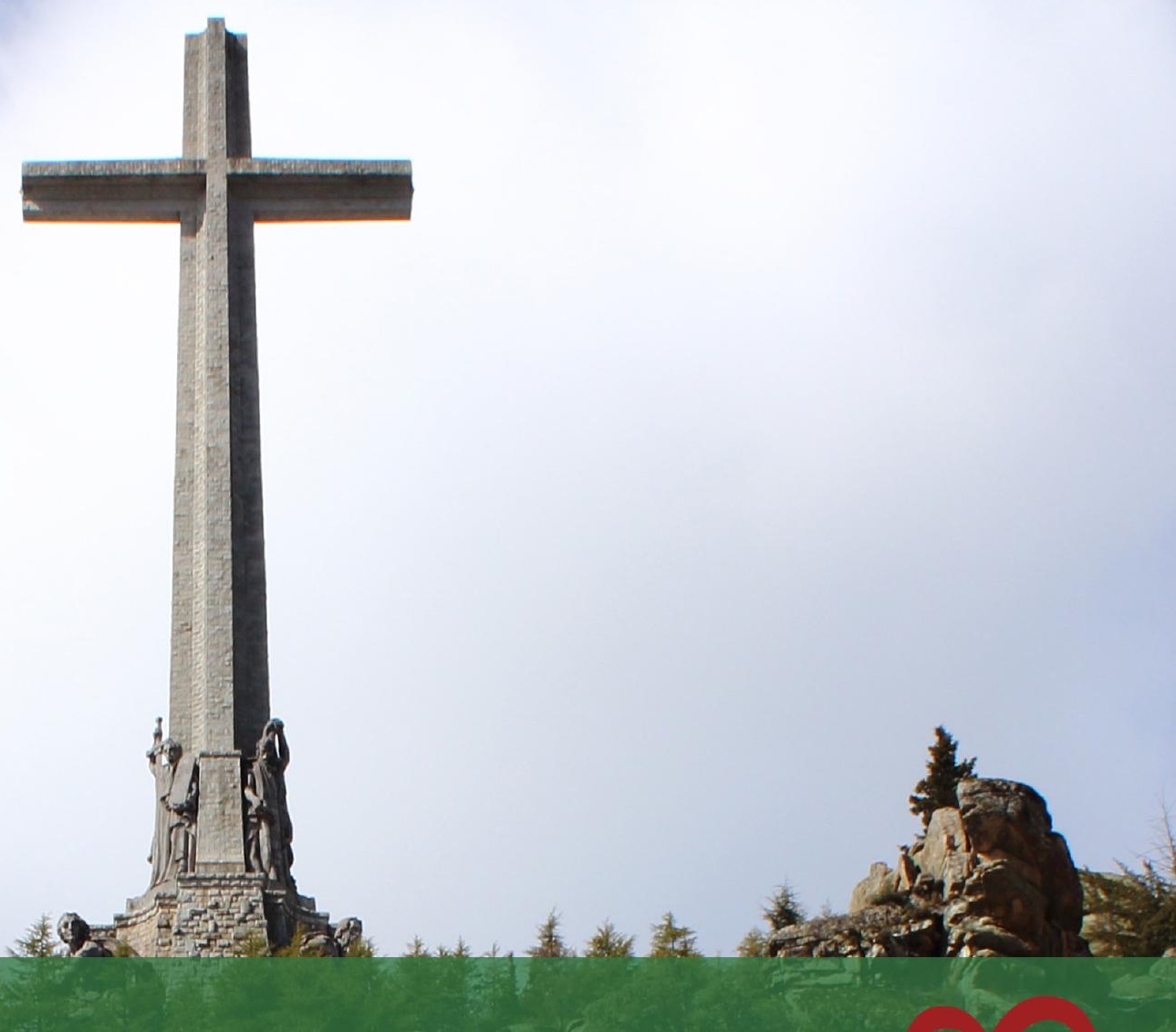

Revista digital de Ciencia y Didáctica de la Historia

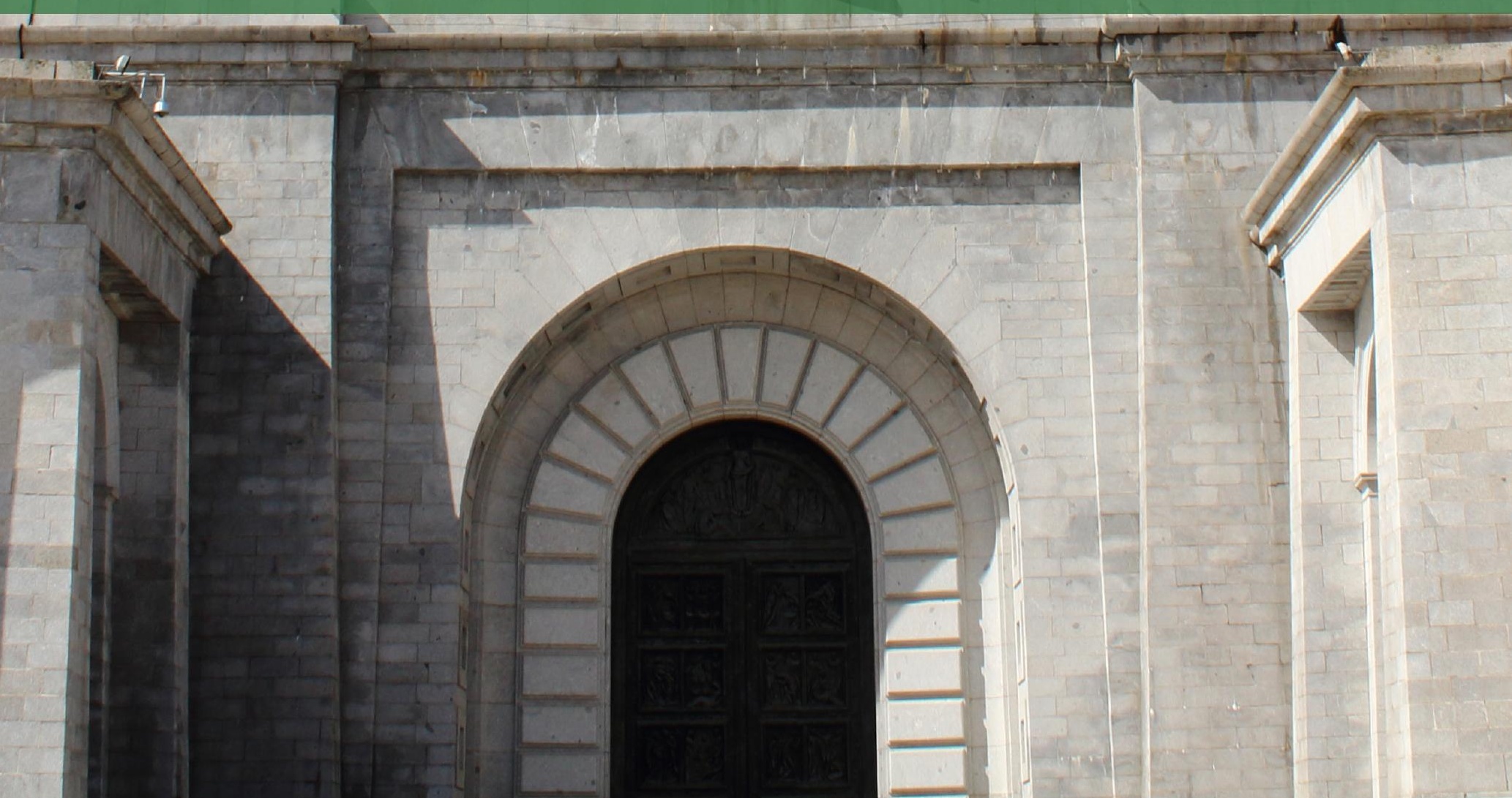




\section{Panta Rei \\ Revista Digital de Ciencia \\ y Didáctica de la Historia}

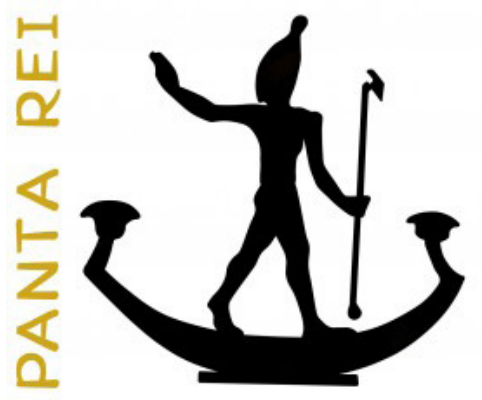

\section{8}

Revista anual

Fecha de inicio: 1995

Revista Panta Rei. pantarei@um.es

Edita:

Centro de Estudios del Próximo Oriente y la Antigüedad Tardía - CEPOAT

Edificio Universitario Saavedra Fajardo.

Universidad de Murcia

C/ Actor Isidoro Máiquez, 9

30007 - MURCIA - ESPAÑA

Teléfono: (+34) 868883890

cepoat@um.es

Web: www.um.es/cepoat/pantarei

Edición 2018

ISSNe: 2386-8864

ISSN: 1136-2464

Depósito legal: MU-966-1995

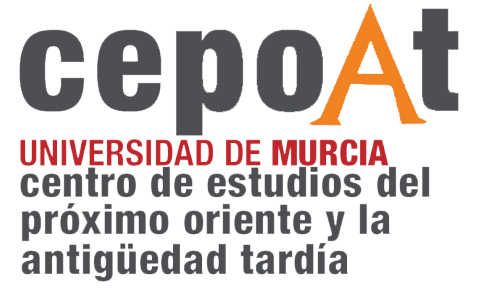

En Portada: Valle de los Caídos, Madrid. (Fotografía de: Adrián Rosell Lucas).

Responsables de los textos: Sus autores.

Responsable de la presente edición: Consejo Editorial Panta Rei. 


\section{CONSEJO DE REDACCIÓN}

\section{Coordinador editorial}

Egea Vivancos, Alejandro

[Didáctica de las Ciencias Sociales, UMU]

\section{Editores}

Botí Hernández, Juan Jesús

[CEPOAT, UMU]

Jiménez Vialás, Helena

[UMU]

López Muñoz, Damaris

[UJA]

Meseguer Gil, Antonio José

[CEPOAT, UNED]

Sáez Giménez, David Omar

[CEPOAT, UMU]

Sánchez Mondéjar, Celso Miguel

[Patrimonio Inteligente]

\section{Secretaria}

Arias Ferrer, Laura

[Didáctica de las Ciencias Sociales, UMU]

\section{Responsable informático}

Martínez García, José Javier

[CEPOAT, UMU]

\section{Traducción y corrección lingüística}

Martínez Martínez, Cristina

[Sociedad Española de Lenguas Modernas]

Albaladejo Albaladejo, Sara

[ISEN, UMU]

\section{CONSEJO ASESOR}

Adroher Auroux, Andrés María [Arqueología, Universidad de Granada]

Albero Muñoz, $\mathrm{M}^{\mathrm{a}}$ del Mar $\left[\mathrm{H} .^{\mathrm{a}}\right.$ del Arte, Universidad de Murcia]

Alia Miranda, Francisco [Historia Contemporánea, UCLM]

Arciniega García, Luis [Historia del Arte, Universidad de Valencia]
Barrio Barrio, Juan Antonio [Historia Medieval, Universidad de Alicante]

Castellano i Solé, Núria [Egiptología, Schola Didàctica Activa S.L.]

Chapman, Arthur [History Education, University College of London, Reino Unido]

Cid López, Rosa María [Historia Antigua, Universidad de Oviedo]

Cobacho López, Ángel [Derecho, Universidad de Murcia]

Cuenca López, José María [Didáctica de las Ciencias Sociales, Universidad de Huelva]

Egea Bruno, Pedro $\mathrm{M}^{\mathrm{a}}$ [Historia Contemporánea, Universidad de Murcia]

Feijoo Martínez, Santiago [Arqueología, Consorcio Ciudad Monumental de Mérida]

García Atienzar, Gabriel [Prehistoria, Universidad de Alicante]

Ginestí Rosell, Anna [Filología Clásica, Katholische Universität Eichstätt-Ingolstadt]

González Monfort, Neus [Didáctica de las Ciencias Sociales, Universidad Autónoma de Barcelona]

González Soutelo, Silvia [Arqueología, Universidad de Vigo]

Haber Uriarte, María [Prehistoria, Universidad de Murcia]

Hernández de la Fuente, David [Historia Antigua, Universidad Complutense]

Hutson, Scott R. [Anthropology, University of Kentucky, EEUU]

Igual Luis, David [Historia Medieval, UCLM]

Irigoyen López, Antonio [Historia Moderna, Universidad de Murcia]

Jover Maestre, Francisco Javier [Prehistoria, Universidad de Alicante]

Mahony, Simon [Digital Humanities, University College of London, Reino Unido]

Marsilla de Pascual, Francisco Reyes [Técnicas historiográficas, Universidad de Murcia]

Martínez-Burgos García, Palma [H. ${ }^{\text {a }}$ del Arte, UCLM]

Mathis, Christian [Didaktik der Geschichte, PH Zürich]

Miralles Maldonado, José Carlos [Filología Clásica, Universidad de Murcia]

Molina Gómez, José Antonio [Historia Antigua, Universidad de Murcia]

Mónica Ghirardi [Historia Moderna, Universidad Nacional de Córdoba, Argentina]

Navarro Espinach, Germán [Historia Medieval, Universidad de Zaragoza]

Noguera Celdrán, José Miguel [Arqueología, Universidad de Murcia]

Ortiz Heras, Manuel [Historia Contemporánea, UCLM]

Panzram, Sabine [Historia Antigua, Universität Hamburg]

Pérez Molina, Miguel Emilio [Filología Clásica, Universidad de Murcia]

Prados Martínez, Fernando [Arqueología, Universidad de Alicante]

Sánchez Ibáñez, Raquel [Didáctica de las Ciencias Sociales, Universidad de Murcia]

Sancho Gómez, Miguel Pablo [Educación, UCAM]

Victoria Moreno, Diego [Historia Contemporánea, UNED]

Vilar García, María José [Historia Contemporánea, Universidad de Murcia]

Vivas Sainz, Inmaculada [H. ${ }^{\text {a }}$ del Arte, UNED]

Zamora López, José Ángel [Próximo Oriente Antiguo, CCHS-CSIC] 

Artículos

El estilo decorativo en las primeras producciones cerámicas en el valle del río Vinalopó (Alicante).

Silvia Martínez Amorós.

Límites históricos del Ateísmo: increencia en la Grecia Antigua.

Ramón Soneira Martínez. .33

Dynamics of Power: an Architectural Reading of the Concentration of Power (Ullastret, 4th-3rd Century BC).

David Jesús Cebrián Martínez.

La mujer como exemplum. Subversión, desafío y resistencia en Valerio Máximo.

Lidia González Estrada.

The narrative framing of violence in teaching resources about the Spanish Conquest of America.

Ángela Bermúdez Vélez y Diego Argumero Martínez.

Modelos de conciencia histórica en el alumnado de Educación Secundaria: tradición, simbología y contextualización en torno a los restos del franquismo.

Diego Miguel-Revilla y María Sánchez Agustí.

La importancia de la contextualización curricular en la enseñanza de la Historia en México.

Enrique Bautista Rojas.

Experiencia didáctica para la enseñanza de la historia contemporánea a través de las fuentes en Educación Superior.

Nayra Llonch-Molina y Verónica Parisi-Moreno 161

\section{Reseñas}

Prados, F., Jiménez, H., Martínez, J.J. (Eds.) (2017). Menorca entre fenicis i púnics / Menorca entre fenicios y púnicos. Murcia: Centro de Estudios del Próximo Oriente y la Antigüedad Tardía de la Universidad de Murcia. 320 págs.

Pete Missingham

Bravo Bosch, M. J. (2017). Mujeres y símbolos en la Roma Republicana. Análisis jurídico-histórico de Lucrecia y Cornelia. Madrid: Dykinson. 333 págs.

Borja Méndez Santiago.

Karp, M. (2016). This Vast Southern Empire: Slaveholders at the Helm of American Foreign Policy. Cambridge: Harvard University Press. 360 pages.

Kevin Caprice.

Livi-Bacci, Massimo (2012). A Short History of Migration. Cambridge: Polity Press. 157 pages.

Alejandro Salamanca Rodríguez. 189

Normas de publicación/Publishing rules 



\title{
Dynamics of Power: an Architectural Reading of the Concentration of Power (Ullastret, 4th-3rd Century BC)
}

\author{
Dinámica de poder: una lectura sobre la concentración de poder a partir de la \\ arquitectura (Ullastret, siglos IV-III a. C.)
}

Cebrián Martínez, David Jesús ${ }^{1}$
University of Cambridge

Aceptado: 19/02/2017

Recibido: $11 / 04 / 2018$

Para citar este artículo: Cebrián Martínez, David Jesús (2018). Dynamics of Power: an Architectural Reading of the Concentration of Power (Ullastret, 4th-3rd Century BC). Panta Rei. Revista Digital de Ciencia y Didáctica de la Historia, 51-71.

ISSNe: $2386-8864$

DOI: $10.6018 /$ pantarei/2018/3

\section{Resumen}

Este artículo analiza el papel de la arquitectura doméstica en la construcción de narrativas de poder y su importancia como elemento clave para profundizar en el estudio y conocimiento tanto del sistema económico como del cambio social en los siglos IV-III aC. La investigación y posterior análisis de la arquitectura doméstica conduce a un conocimiento más profundo de la organización social además de aportar claves sobre la ideología imperante. Por otra parte, el cambio social se refleja a menudo en el hogar de la misma manera que en el patrón de asentamiento. Después de llevar a cabo el análisis empírico, la contribución de este ensayo se fundamenta en la tesis de que el poder puede ser concentrado.

\section{Palabras clave}

Historia Antigua, cambio social, patrones socioculturales, arquitectura, modos de vida.

\begin{abstract}
This paper discuss the role of domestic architecture in the construction of narratives of power and its importance as a key feature to determine and analyse both the economic system and the social change in the 4th-3rd century BC. On the one hand, scrutiny of domestic architecture is a fruitful way by which to draw out a deeper insight with respect to social organisation, as well as being an indicator of ideology. On the other hand, social change is frequently reflected in the household in the same way as it is in settlement structure. After taking into account the empirical analysis, this paper contributes by determining that power can be concentrated for a number of reasons.
\end{abstract}

\section{Keywords}

Ancient history, social change, sociocultural patterns, architecture, life style.

1 Para contactar con el autor: David Jesús Cebrián Martínez. University of Cambridge. david.cebrianmartinez@ cantab.net. 


\section{Introduction. Initial remarks}

The conclusion we reach is not that production, distribution, exchange and consumption are identical, but that they all form the members of a totality, distinctions within a unity. Production predominates not only over itself, in the antithetical definition of production, but over the other moments as well. The process always returns to production to begin anew (Marx, 1973, p. 99).

This paper is concerned with the dynamics of power on the far north-east of the lberian Peninsula, with the aim of defining these processes through a dataset provided by one aristocratic architecture, the so-called zone 14, its material evidence, and the necropolis of Ullastret. The nature of the site and the data itself has led me to the formulation of an idea, the concentration of power, which in principle has been specifically conceived for the analysis of this case-study and a better understanding of this essay. For analytical purposes, moreover, it is my aim to explore the dialectics of power by articulating various discussions with the aim of gaining a better understanding thereof. It will be constructed upon the close bond between domestic architecture and the form in which the lineage conceives its ideology and the relations of power.

In Figure 1 we can appreciate the location of Ullastret in the Iberian Peninsula, near the Greek outpost of Emporion. The settlement is situated amid the basins of the rivers Ter and Daró (Martín \& Plana, 2001a). The archaeological site is bounded to the north and west by the mountainous areas of Rhode and l'Albera, that is, the Pyrenees. The North-west is delimited by the mountains of Garrotxa and Montseny, in the basin of the river Muga. The South-west is delimited by the mountain system of Les Gavarres and south of this are the mountains of Gironés-La Selva. The territory is traversed by numerous river basins which run from the Muga basin to the Tordera basin. In general terms, the landscape, particularly the coastal line of north-east Catalonia, largely consists of marshes and wetlands.

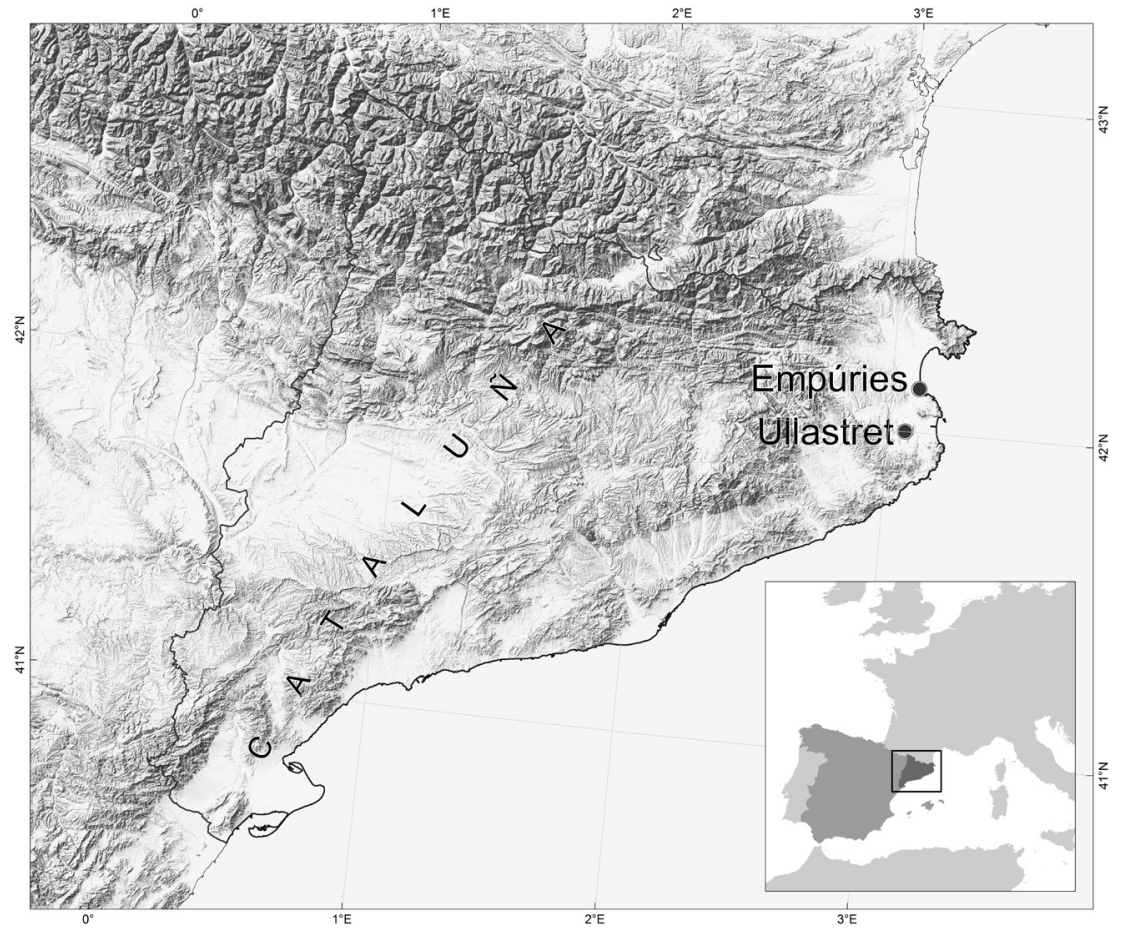

Figure 1: Map of the location of Ullastret and Emporion. By David Redhouse, University of Cambridge. 
The landscape and settlement pattern are two crucial elements in understanding the dynamic of power and the role played by Ullastret in the formation thereof. As regards the landscape, this is composed of a number of indigenous settlements, of which Ullastret, formed of two oppida, the Puig de Sant Andreu and the Illa d'en Reixac, would appear to be the chief site, coupled with the Greek colony of Emporion. The settlement pattern of this territory has been described as hierarchical (Belarte, 2013; Sanmartí, Martín, \& Plana, 2015). Ullastret is at the top of the pyramidal axis, with a secondary urban settlement on the ridges of the territorial hinterland, Sant Julià de Ramis, which has been associated with a necropolis, Pla de l'Horta, of the Early Iberian Period (Sanmartí et al., 2015). Coupled with the latter, there are a number of rural settlements, among which Pontós is a prime example.

Ullastret is a settlement with a polynuclear form which emerges at the dawn of the Iron Age when local groups constructed round dwellings in the $7^{\text {th }}$ century BC (Martín \& Plana, 2001b). Viewed broadly, however, as has been written by Sanmartí (2004), one ought to admit that the evidence and knowledge we have of this period is, at best, thin and scarce. This pre-Roman urban complex is formed by two oppida, the Puig of Sant Andreu and the Illa d'en Reixac, the artisan quarter of GouBatlle, the necropolis of Serra de Daro and some small habitats such as Camp Davant. This territory was inhabited by one of the Iberic peoples mentioned by the written record, the Indigetae.

Let us now briefly review the urban layout of Ullastret and some of its main features, such as the existence of elaborate water reservoirs, an impressive defensive system, and the well-attested presence of two temples with ground plan in antis. As regards these features, the settlement was fortified by the second half of $6^{\text {th }}$ century $B C$, the walled area occupying a surface of approximately 3 ha (Prado, 2010; Sanmartí, 2004). Three types of towers in the rampart have been unearthed, circular, quadrangular, and polygonal. It has been suggested that the circular tower is the earliest documented type and appears to be a continuation of the typology utilised in this part of the Mediterranean (Prado, 2010). It is particularly noteworthy that this type of circular tower seems to have converged with the local groups of the Early Iron Age, for which one is driven to suppose, if this analysis is correct, that the circular tower is a feature of the early hierarchical organisation of the kinship group. Another feature that stands out in the layout of the settlement is the large number of gateways, eight, that have been discovered along the rampart.

In broad outline, one might also draw attention to both the drainage system of rainwater and the system to collect rainwater in cisterns, attested by the four water reservoirs discovered in Ullastret. The latter is indicative of the urban complexity of this site. The rainwater was collected from the roofs of the houses from which it flowed to cisterns (Codina, Heinrichs, Lara, Molinas, Prado, \& Schön, 2015). But there is more. The analysis of the cisterns and their hydraulic mortar have revealed that: (1) the stone used in the construction of the cisterns comes from local quarries and (2) perhaps most importantly, there seem to be analogies with other models documented in the neighbouring settlement of Emporion and in the Punic sphere of influence in north Africa (Codina et al., 2015). This denotes the extent to which Ullastret is interlocked with the Mediterranean koine and, substantially, its important role within the indigenous world.

\section{Household and domestic architecture}

It may perhaps be wise to begin by underlining the relevance of architectural analysis in the construction of narratives of power, particularly when, as we shall see further on, from all across the ethnic landscape the distribution and type of dwellings determines, to some extent, the way in which the natural resources were exploited. Over recent years household archaeology has greatly contributed to gaining a deeper insight into social organisation and the dynamics of power within a given culture. The household has been defined as an economic unit through which inhabitants partake in productive activities (Santley \& Hirth, 1993), and as the primary spatial unit wherein domestic economy is developed through various strategies (Hirth, 2009). In addition, as already noted by various scholars, there seems to be a close link between the composition and form of the 
household and the access to natural resources (Horne, 1991; Santley \& Hirth, 1993). It is equally feasible to measure the wealth of a determined dwelling by analysing its architecture, whilst at the same time we may tackle issues related to status and different economic features of a given site or landscape (Kamp, 2000).

Let us now review more closely the Iberian household, of which we have several examples in the Catalan area. To begin with, there have been attempts to categorise the lberian household according to its size and thus, various typologies have been proposed, for instance, Belarte (2013) and Grau (2013). The Iberian dwellings have been grouped by Belarte (2013) into two groups depending on their size, the so-called "type a" and "type b" (p. 78). Type a encompasses the most simple category of dwelling, with one or two rooms and a ground plan of about 20 to $35 \mathrm{sq} \mathrm{m}$. The so-called type $b$ embraces larger dwellings with more complex layouts and with a ground plan that ranges from 40 $\mathrm{sq} \mathrm{m}$. to $800 \mathrm{sq} \mathrm{m}$. as with the zone 14 in Puig of Sant Andreu and zone 15 in Illa d'en Reixac. On the basis of the latter, Grau (2013, p. 64 and 71) has proposed a classification into two types too, Monofocal and Plurifocal, depending on the type of household and hence the type of family, that is, nuclear family or extended family. This typology is grounded, at least to some extent, in economic parameters, given that the simplest type, Monofocal, would have a ground plan of 25 to $50 \mathrm{sq} \mathrm{m}$. with one, two or three rooms and would be associated with peasants and a segment of the society with scarce economic resources (Grau, 2013). Type Plurifocal of dwelling would be composed of the largest dwellings and inhabited by extended family, whilst at the same time the economic activity would seem to be slightly different and linked to trade rather than agriculturist- related. The so-called dwelling 1 in Castellet de Bernabé is a prime example of a Plurifocal dwelling correlated with a model of extended family (Grau, 2013). Large dwellings with complex layouts are scattered across the landscape in the Catalan area. Buildings 1, 2, and 3 in Castellet de Banyoles, the dwelling 201 in Alorda Park, and the large dwellings of Pontós, coupled with the aforementioned zone 14 and zone 15 in Ullastret, are indicative of a type of dwelling that would appear to be related to the elite class and, as with the necropolises during the Iberian period, do not tend to be documented in all settlements.

Through the reading of households, we can frame questions about inequality and social identity. Of what type were the relationships between domestic architecture and power? Can we tackle dynamics of power through the analysis of households? We should examine these matters in order to reopen new dialogues with which to raise new stimulating questions concerning social identity and power. Similarly, one would suggest an approach to the Iberian domestic architecture from various perspectives, including relationships of power and ideology as well as worldview, because of my conviction that the separation of these spheres of knowledge is an insight belonging to the French enlightenment.

As stated elsewhere, the Iberian household appears to have been inhabited by both a model of the nuclear family and of the extended family. With regards to our subject of study, the zone 14, Belarte and Grau have raised the possibility of interpreting the zone 14 as the residence of an extended family (Belarte, 2013; Grau, 2013). Without dismissing this possibility, and other plausible interpretations, the large number of rotary quern stones and furnaces found, both features normally associated to status (Grau, 2013), raises the question of whether zone 14 housed an extended family or it had external people who developed a determined economic activity (Belarte, 2013). Be that as it may, it is certainly difficult to tackle this issue in a world in which the written record had not yet been deciphered. Despite the aforesaid facts, kinship bonds appear to have been replaced at some point, as we shall see further on, by a social organisation structured in groups of power within the leading lineage as the necropolis of Ullastret appears to suggest through the spatial layout of its burials, although still with a deep-seated nexus between lineage and Gaia. With a view to further supporting this idea, as noted by Sanmartí et al. (2015), the political organisation during the $4^{\text {th }}$ century BC shifted from one grounded in kinship bonds to another whose base lay in the territory. The latter is in concordance with Marx's affirmation that "the tribes [Stamme] of the ancient states were constituted in one of two ways, either by kinship or by locality. Kinship tribes historically precede locality tribes, 
and are almost everywhere displaced by them" (Marx, 1979, p. 94). In broad outline, one suspects that the interaction between relations of production and productive forces -which is understood by Marx (1971) as the interpretative key to understanding social change- underlies the solid core of the concentration of power and the change in social structure during the course of the $4^{\text {th }}$ century B.C. in the ethnic landscape of Ullastret, which materialised in the relationship between farmsteads, oppidum, and lineage. De facto, this interpretation is increasingly supported by the archaeological evidence, given that the number and size of silos had increased enormously during this century (Pons, Gago, Fernández \& Bouso, 2000).

\section{The concentration of power: opening insights}

The core idea of this essay draws on the assumption, as we will discuss at length below, that power may be concentrated for various reasons. This phenomenon is evidenced in the necessity to organise the economy within a given agrarian society in order to have agricultural surplus with which to trade; the desire to control natural and economic resources, since the development of power has always signified the accumulation of wealth; climate change such as long dry periods and famine; It also arises when it is necessary to confront either an external or internal enemy by accumulating the prerogatives of government, as in the event of the saga of the Etruscan kings of Rome; indeed it is also discernible from straightforward observations that the concentration of power occurs at moments wherein inner contradictions and tensions appear on the social horizon expressed by the realm of inequalities, as in the instance of the Decemviri in Rome. Furthermore, this may be reflected within the household through some architectural features, perhaps in zone 14 the most significant in terms of accumulated power being the seizure of a tower by taking an initiative burdened by symbolic power, together with the seizing of a stretch of rampart with a gateway. It is noteworthy, moreover, that some of the material evidence hints at this suggestion, such as the large number of offerings, jaws, and spiked skulls.

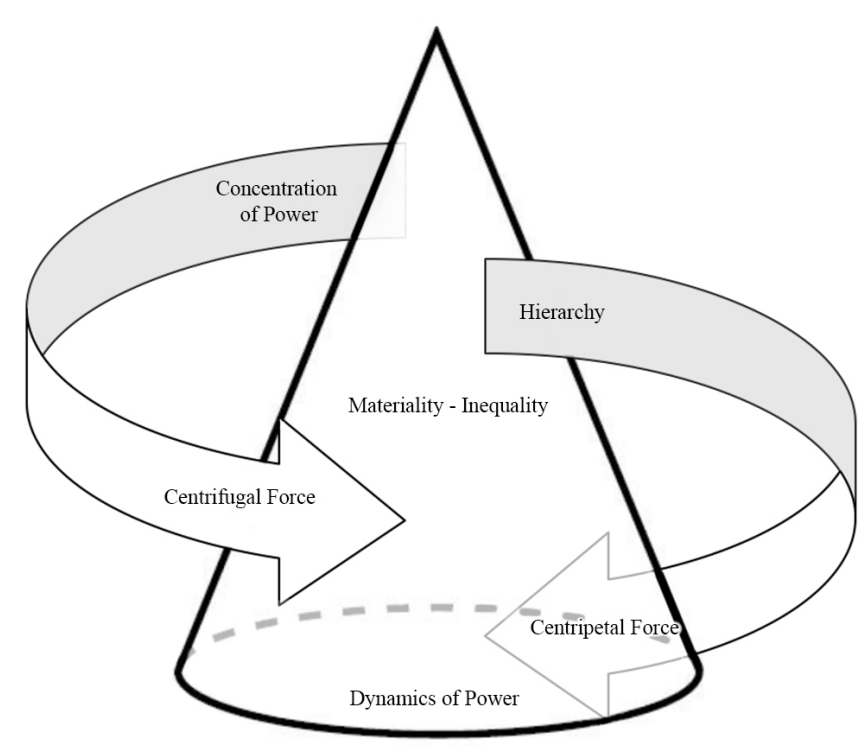

Figure 2: Outline plan of the concentration of power. By the author. 
At a more abstract level, in strongly hierarchical societies the accumulation of wealth shows the hierarchy and the social stratification, whereas the concentration of power operates within the sociopolitical sphere and denotes the ability of economic, political, and ideological hegemony by a reduced segment of the elite class which also has the capacity to rule exerting coercion. Consequently, this does not replace a concept of hierarchy; on the contrary, as a model for emergent power it expands our understanding on narratives of inequality, thus aiding us in the analysis of architectural and material evidence through which to address social identity reflected in the household. It is further suggested that, in the theoretical frame, concentration of power is the process whereby an ideology is explicitly channelled for imposition by determined groups of power upon the lineage, an ideology composed of miscellaneous values aligned with a given cultural tradition and with concrete psychological factors through which to model the collective behaviour of the lineage, whereas hierarchy is the structure, it is the materialisation of this process, personified in the binomial formed by materiality-inequalities.

As regards the formation process of social hierarchy in Ullastret, its development may be confirmed by the $6^{\text {th }}$ century BC on the basis of demographic growth and trade with Mediterranean agents (Sanmartí, 2004). Seen in this light, a central issue is to delimit the degree to which social stratification can be envisaged in the archaeological record, and de facto, it does show, as we will see, in the funerary sites, domestic architecture, and the percentage of imported goods found in this territory (Sanmartí et al., 2015).

The scarce number of necropolises for this period, as well as the reduced number of burials, is one of the most convincing arguments in this regard, since 196 out of 212 documented burials are concentrated in the necropolises of Burriac and Ullastret, what has convincingly lead Sanmartí to assert that the necropolis corresponds with the political power and is wherein the principal lineages are buried (Sanmartí et al., 2015).

As already aforementioned, domestic architecture is a clear indicator of social stratification. The appearance of complex dwellings is documented in Ullastret as early as the $5^{\text {th }}$ century BC (Belarte, 2013). Large dwellings have been discovered in Puig de Sant Andreu and I'llla d'en Reixac correlated with the elite and dated during the $4^{\text {th }}$ century BC, precisely a period of time in which the rural habitat enormously increased due to, perhaps, an agrarian intensification (Sanmartí et al., 2015). The fact is, however, that there are other large dwellings, in their first phase of excavation, whose location lay around zone 14, with which they share a similar typology (Sanmartí et al., 2015). It leads to the supposition that, perhaps, the complex dwellings were located in this part of the oppidum.

Ullastret is remarkable for the large number of imported materials, from $12 \%$ to $15 \%$ of the total, with a percentage of $23 \%$ of amphorae. Again, this ratio is incremented during the $4^{\text {th }}$ century BC (Sanmartí et al., 2015). The necropolis of Ullastret also stands out due to its prestige goods, including attic vessels used as funerary urns, fibulae, and belt buckles (Sanmartí et al., 2015).

In effect, as can be seen in Figure 2, the hierarchy and the concentration of power are interlocked and feedback to one another within a rotating spatial framework, and thus pave the way to receive nourishment from the same root, the power itself. One could possibly argue that the separation between the concentration of power and hierarchy is a methodological one only, as they form a unity in the same way as the base and the superstructure in Marx. We shall recognise this unity as a dialectical process dynamically embedded within the inner frame of the lineage structure. Indeed, the concentration of power begins when there would appear to be a resource subject to appropriation. Seen in this light, the concentration of power is developed at the same pace as the relations of production, albeit that the embryo was in society as shown by the necropolis, the rampart, and the enormous defensive ditch of Ullastret. The power is subdued by tensions and contradictions that we would envisage, on the one hand, as a centripetal force; this is the nature of power, its own manifestation, its tendency to accumulate that allows power to be articulated at a given point in history in a determined form. On the other we can discern a centrifugal force embodied by the historical circumstances that permit the reorganisation of power with the finality of reinforcing itself, as a result of which appear the groups of power that will articulate the social identity on the basis 
of an agrarian economy during the Iron Age. It is the dialectical motion of History that determines that power adopts one form or another. As an example, the power in Rome during the period of the monarchy, the republic and the empire adopted various forms depending upon the historical circumstances.

The archaeological outline of the concentration of power in Ullastret is the following:

- The conditio sine qua non by which this process began lies in the economic base, that is, the agrarian production and a move to mono-cropping, which according to Jones (2007) could be a signifier of social change.

- The next natural step is to develop the storage capacity, that is, the so-called field of silos. As noted by Sanmartí and Santacana (2005), there was during the $4^{\text {th }}$ century BC a large increase in the number of silos. This could be related to the supply of tribute, for which a centralised social identity is required (Jones, 2007). It is the moment in which, according to Codina, Martín and Prado (2007), the enlargement and refurbishment of the oppidum occurs. It is precisely then when zone 14 was constructed.

- In the course of the $4^{\text {th }}$ century BC the specific historical circumstances were laid as to trigger the process of concentration of power in Ullastret. Emporion is the economic catalyst that activated the switch to a social identity grounded in the groups of power. Since Emporion had the key of maritime trade and thus of the exportation of grains, this gives rise to the development of a dual economic system and the strengthening of both the indigenous social identity and the Ampuritan social identity.

\section{The annexation of the tower and the gateway number 8 . To whom does the production of iron and its control belong?}

Let us move on to the core of this paper, the reading of the functional distribution of space within this aristocratic architecture and dynamics of power. One should like to begin by putting forward an insight that will structure both the interpretation and the development of this essay. In spite of the interpretive difficulties, but increasingly supported by the weight of the archaeological evidence, the so-called zone 14 was in reality the palace of Ullastret. It was located between two towers, adjoining a stretch of the rampart in a similar way as the large dwellings of Lattara (Casas, Codina, Margall, Martín, \& Prado, 2004). This is a trapezoidal building although the shape is virtually rectangular and it occupied an area of approximately $800 \mathrm{~m}^{2}$ (Casas et al., 2004; Codina et al., 2007; Codina, Martín, \& Prado, 2012). In truth, we shall bear in mind that the dimensions of the productive area within a household might be a clear indicator of rank and status (Horne, 1991).

Of particular interest, moreover, is the fact that the palace had to appropriate one of the towers, number 3, and also had a private gateway (Casas et al., 2004). Furthermore, to take possession of the tower, the palace had to annexe a throughway, the so-called zone 23 which gave access to the tower (Casas et al., 2004). At this point, it becomes pertinent to raise a crucial question that will enhance our understanding of the dynamics of power in Ullastret, why was the tower taken over? Here underlies a relational dialectic in which the palace and therefore the head of the lineage became the dominant feature and the tower is turned into a subordinate extension to the palace. Furthermore, one would suggest that the seizure of the tower would equate to an annexation of power by the leading lineage and the hegemonic groups which constituted its inner pyramidal structure, contextualised within the shift of the social identity grounded in kinship bonds toward another wherein the power is fractured into various groups. Following this line of argument, the subjugation of the tower does not seem to have had a functional role but rather a symbolic one. In a certain sense, one would hypothesise that the capture of the tower was an action, to some extent, burdened with ideology and through which the head of the lineage could display his leading role, becoming inseparably merged with concepts of power to the lineage. The net effect is that the counterbalance of the former dynamics of power broke down, giving rise to a different dialectical process. 


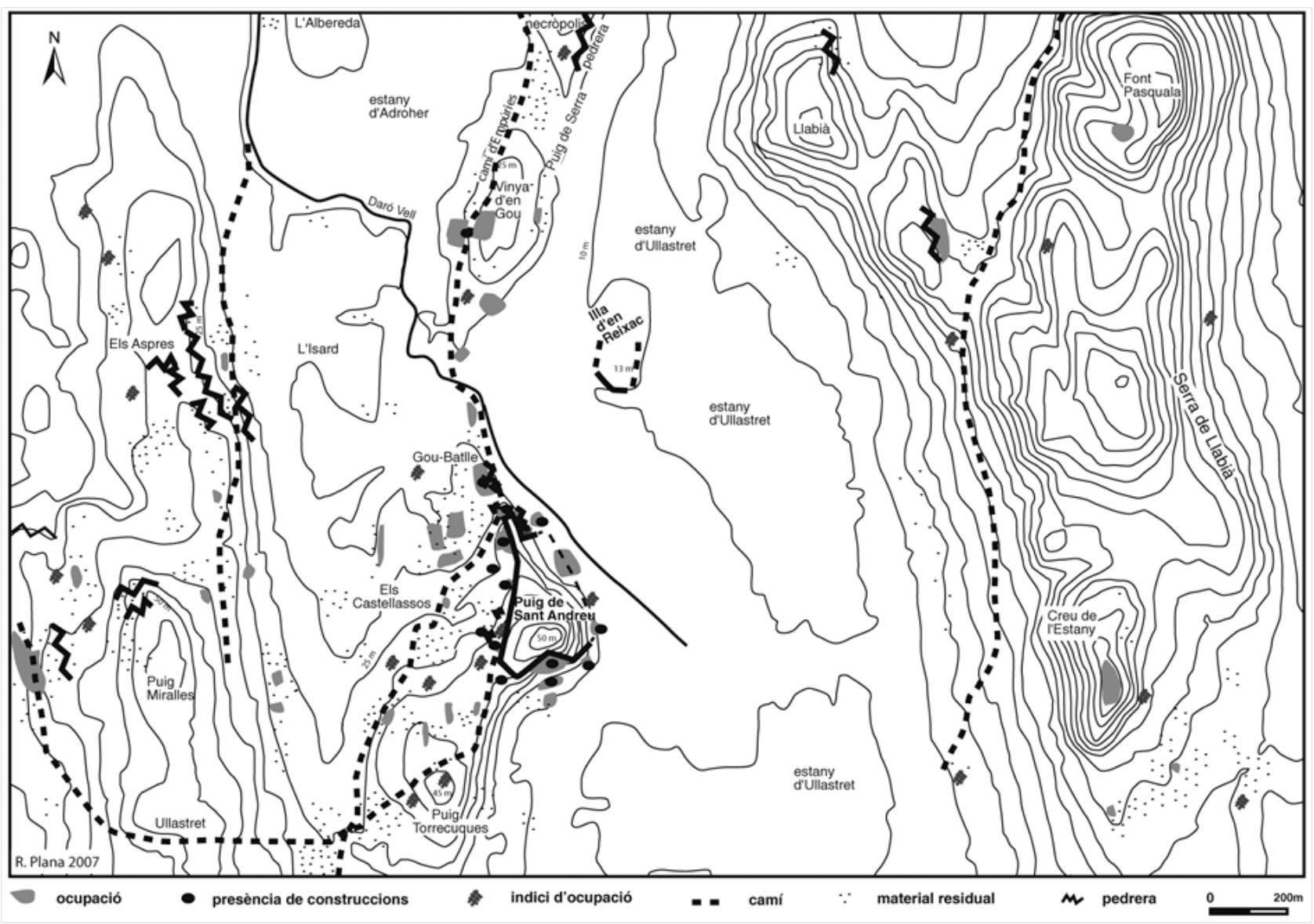

Figure 3: Ground plan of Puig of Sant Andreu and its relationship with the settlement pattern. After the research of Martín and Plana (2012).

After examining the consequences of the subjection of the tower, we now turn to the analysis of the metallurgical workshop. In this light, there could have existed a correlation between gateway 8 and the ironworking workshop with Gou-Batlle, the metallurgical artisan quarter, having evidence of bonds with the landscape, agricultural production and consequently with landholding through the assemblage of agricultural tools. In the broader sense, Gou-Batlle is a metallurgical centre, as can be appreciated in figure 3, located 100 metres from Puig of Sant Andreu, nearly halfway between this settlement and the Illa d'en Reixac (Codina, Gay, Martín, \& Plana, 2008; Codina et al., 2012). As a consequence of the inherent features of the site, this stratum can be ascribed not to habitational structures but rather to workshops (Codina et al., 2012). Owing to the surprising number of metallurgical furnaces unearthed in the palace, three, it is hence likely that a connection exists between gateway 8 and Gou-batlle.

From this perspective, one might raise the question that it is feasible that the iron production, that is, agricultural tools and weaponry, could have been concentrated and controlled by centres of power such as the palace. Similarly, the extensive number of agricultural tools associated with the large dwellings in the Catalan area, has emphatically led Sanmartí et al. (2015) to set forth the idea that the elite controlled the means of production. In this regard, as we can see in Figure 4, there is a round structure very close to the metallurgical workshop, enclosed within a rectangular structure which opens towards the southwest. One could say that this finding may be interpreted as a water well, that is, the palace probably had its own supply of water. As noted by Horne (1991), there seems to be a correspondence between the availability of water and rank. We have, furthermore, as we 
shall see, the ditches RS 70, RS 66, RS 53 in Gou-Batlle (Codina et al., 2008, Figure 4). Owing to the essential attributes of production, it might be assumable that these ditches were used to supply water to the workshops. What is of interest to this discussion, however, is the fact that both spatial units were marked out by offerings. In one of the silos of Gou-Batlle (SJ-72) the remains of two horses were unearthed (Codina et al., 2008). It would appear that the site was ritually delimited by a social boundary, that is, the burial of the aforesaid horses would aim a sacralisation of the space in the name of the elite class, given that in all probability only a reduced faction of the inhabitants had the right to the possession of a horse. From the above discussion, it is reasonable to suppose that GouBatlle was consecrated by the upper class, since these types of offerings only appear in Ullastret in spatial units associated with the gentry such as the necropolis. In this context a comparison emerges, for it has been argued the role played by animal offerings in the British Iron Age is a marker of social rank (Pearson, 1999).

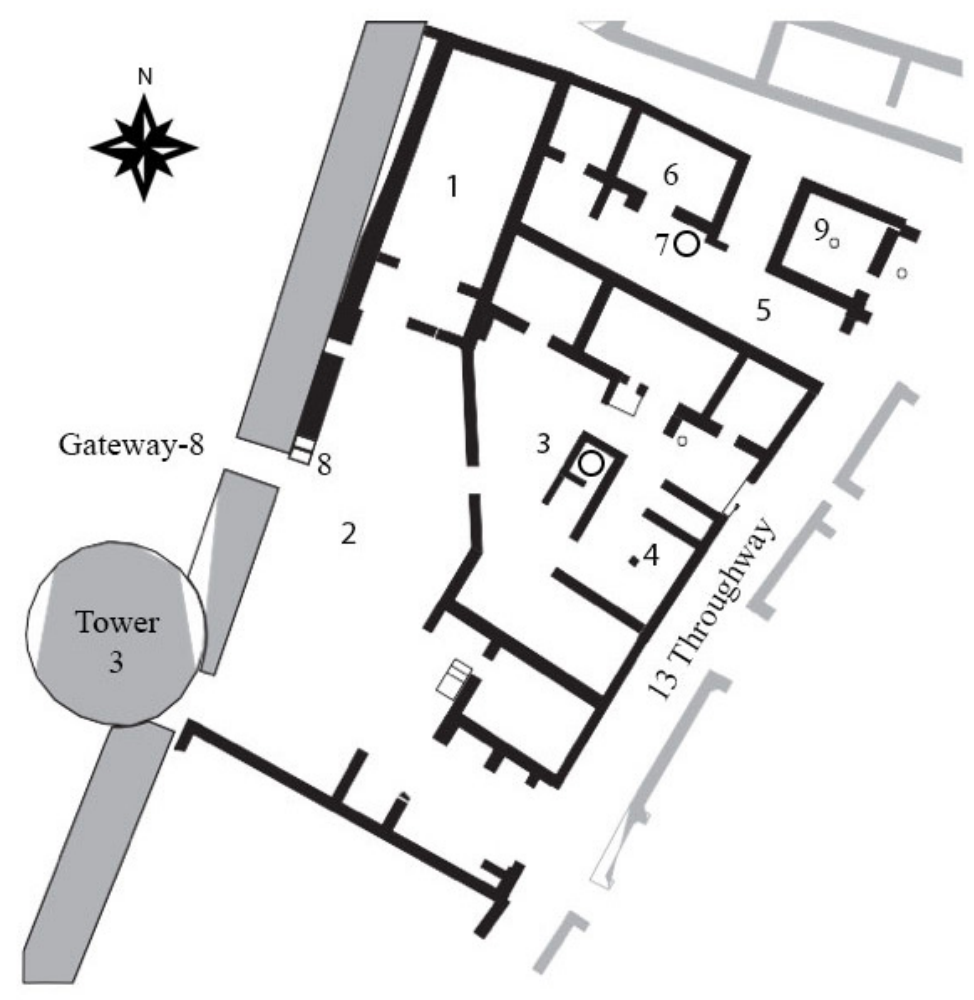

Figure 4: 1 Lavish room, 2 Courtyard, 3 Water reservoir, 4 Metallurgical workshop, 5 Storage area, 6 kitchen, 7 domestic furnace, 8 staircase, 9 room where tribute was paid? Based on Casas et al. (2004).

As we have seen at length, the role of animal offerings is crucial in understanding the inner dynamics of power in Ullastret. Notwithstanding, it is worth noting that several foundational offerings were in the palace, 73 were found, all ovicaprid except one dog offering and one composed of seashells (Casas et al., 2004; Codina, Martín, Nadal, Prado, \& Valenzuela, 2009). Each foundational offering was composed of three animals, a factor that indicates the relevance of the role of livestock coupled with the agriculture for the palace. What is more, it is reasonable to suppose that the upper class possessed its own herds. Indeed, it has been insinuated that the wealthiest dwellings may have owned their own flocks (Horne, 1991; Kamp, 2000). If, as we may assume, this analysis is correct, one may at least infer that animal offerings symbolise the sacred ties of the groups of 
power with both metallurgy and agriculture. Concomitantly, offerings denote its capacity to articulate the dialectic of power and inequalities, whereas at the same time, operate in the arena of lineage production relations, dialectically embodied through an economic system which, as will be seen, had a dual character. There has been put forward, furthermore, and to a certain degree we ought to consider it as a possibility, the role that the offerings could have played in the celebration of banquets with which to gain personal prestige and consolidate the relationships of power within the lineage (Belarte \& Valenzuela, 2013). It is a metaphor, in short, about to whom the means of production of the Iron Age belonged.

\section{Architectural reading: towards a sociological analysis of the space}
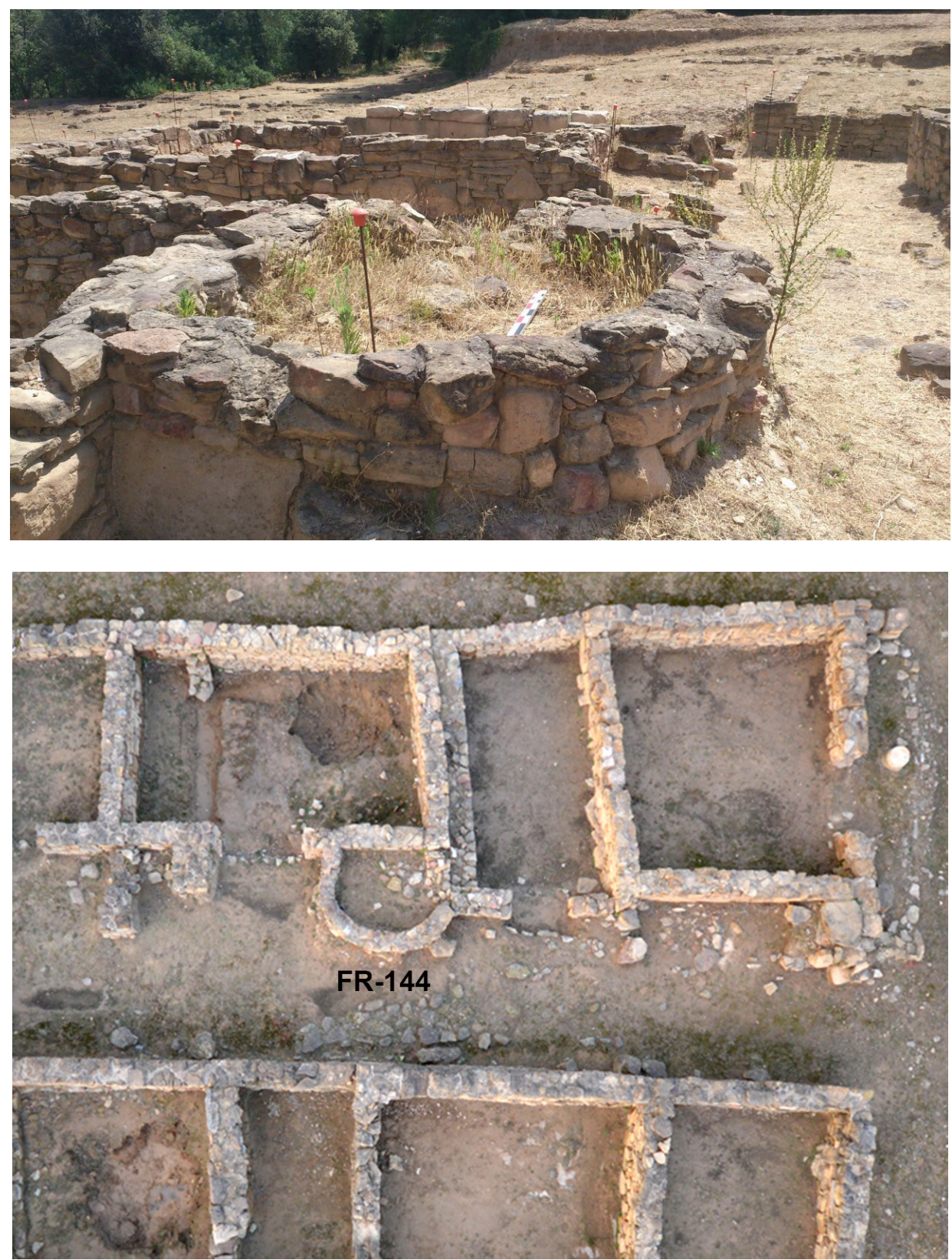

Figures 5a and 5b: domestic furnace. Source: Archivo del Museu d'Arqueologia de Catalunya-Ullastret.

Let us take a different track, yet one which, to be more precise, will lead us to the scenario of political theatre by articulating the natural laws of the political economy. Let us begin by offering a 
very schematic sketch of the lavish room and its relationship with a large domestic furnace of 2.5 metres width as can be seen in Figures $5 \mathrm{a}$ and $5 \mathrm{~b}$, placed beside a large room with two hearths, number 8 , along with another domestic furnace of a smaller size. Sector 8 has been interpreted as the kitchen of the building, with a ground plan of $20.52 \mathrm{~m} 2$ (Codina et al., 2012). One might argue that, in theory, the dimensions of both the large furnace and the cooking facilities are dialectically connected to the hearth room. It will be argued that the core function of the large gentilic space was supposedly for hosting feasts with a view to the acquisition of symbolic power and the maintenance of inequalities, as appears highly probable by the number of pieces of ceramic ware, connected almost entirely with drinking, found in this sector (Casas et al., 2004). It is potentially feasible that the number of Punic Ebussitan amphorae and pieces of Attic black gloss ware found in the majestic room is linked with the role and scale of feasting activities to ensure the consolidation of the groups of power within the lineage and their grade of access to the communal resources. What is beyond question is that through hosting these banquets, the head of the lineage would gain prestige with which to articulate his leadership and create relations of reciprocal obligations by which to uphold his position in the political scene. Closely tied to this discussion is the silicernium unearthed in the necropolis (Martín, 2008), given that, supposedly, it was known what a banquet was.

The ground plan of this sector was over $60 \mathrm{~m}^{2}$ and, as can be appreciated in figure 6 , it was accessed from the patio and also through the main entrance via the porch. The floor was of lime mortar with a gravel preparation. In the centre of the lavish room a square hearth of considerable dimension, $2 \mathrm{~m}^{2}$, was found. The walls were lined with hydraulic mortar and painted with a broad band of bluish black. The lower part of the wall as well as the rest was painted white with red lines. Within this spatial unit several offerings of ovicaprid, one offering of dog and another composed of seashells were found (Casas et al., 2004). Although the building was structured around the courtyard, this sector seems to be the focal point of the entire household and it would appear to express at a micro scale a similar narrative as the palace does on the whole. So much so that, if on the one hand the large hearth room is related to the entire building through the entrances, on the other the palace is fully merged with the rampart, the settlement, and two of the chief gateways through the enormous staircase of the courtyard, figure 7 , which linked the palace via the walkway of the rampart with the oppidum as a whole.

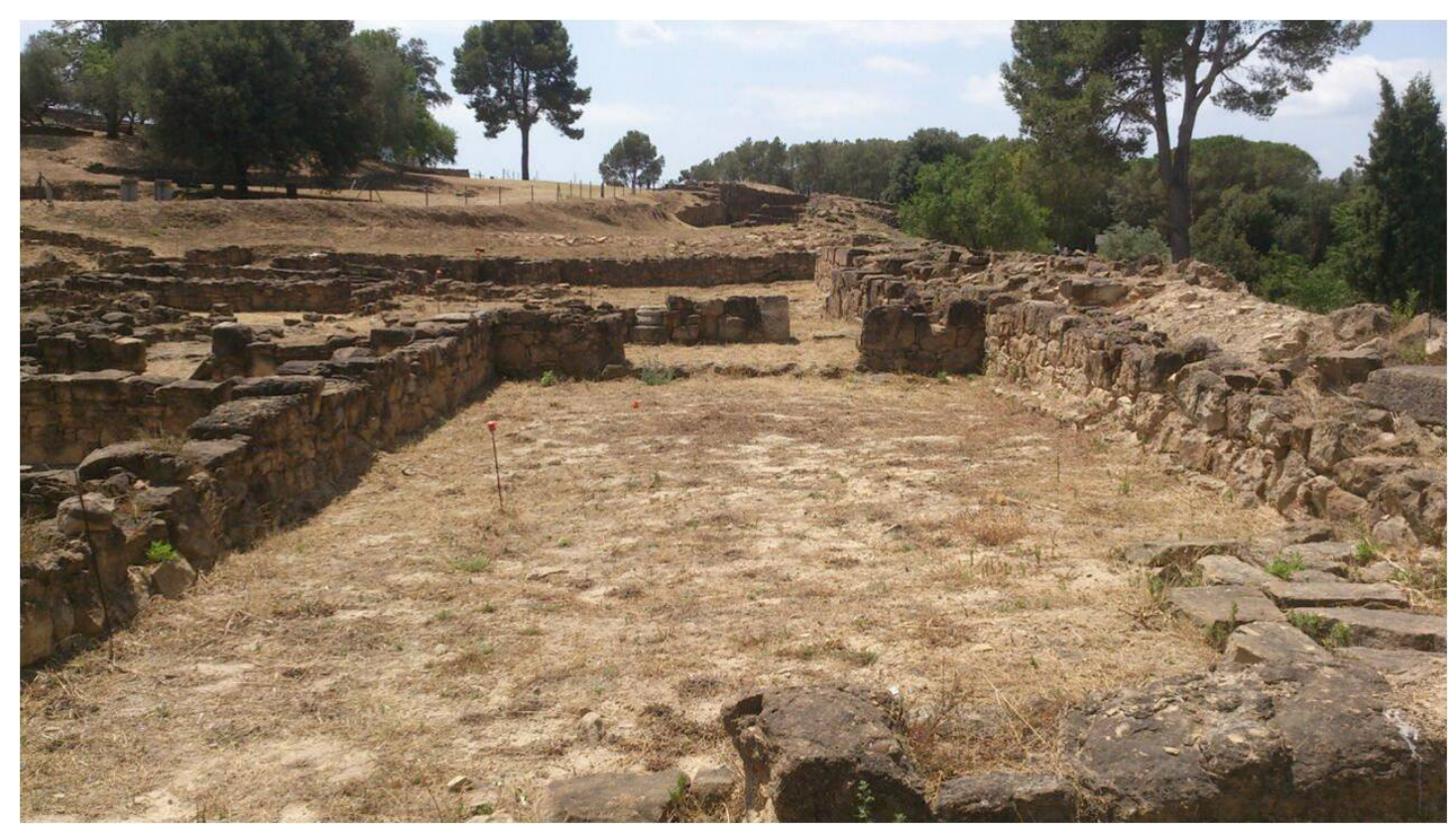

Figure 6: Lavish room. By the author. 
It is hence important to bear in mind the possible bias in terms of articulating the space played by the varied spectrum of entrances to this building, insofar as all of them end up at this sector. One could convincingly hypothesise, at a given moment, that the display of spiked skulls on the facade of the building and along the main entrance corridor to the lavish room, had the aim of interconnecting ideologically a communal space, the throughway, with the focal symbol of the palace. In parallel with this interpretation, a priori, the alluded interconnection between the hearth room and two of the principal gateways through the staircase and the walkway of the rampart, could be explained, in part, as a seizure of an alleged ancestral tribe consuetudinary law by the leading lineage. The latter is suggested by virtue of its symbolism as communal spaces which lie at the very heart of the settlement structure, and particularly by making visible to the rest of the kinship group the eternal bonds of the dominant lineage with the defensive system and hence with the core axis of the lineage.

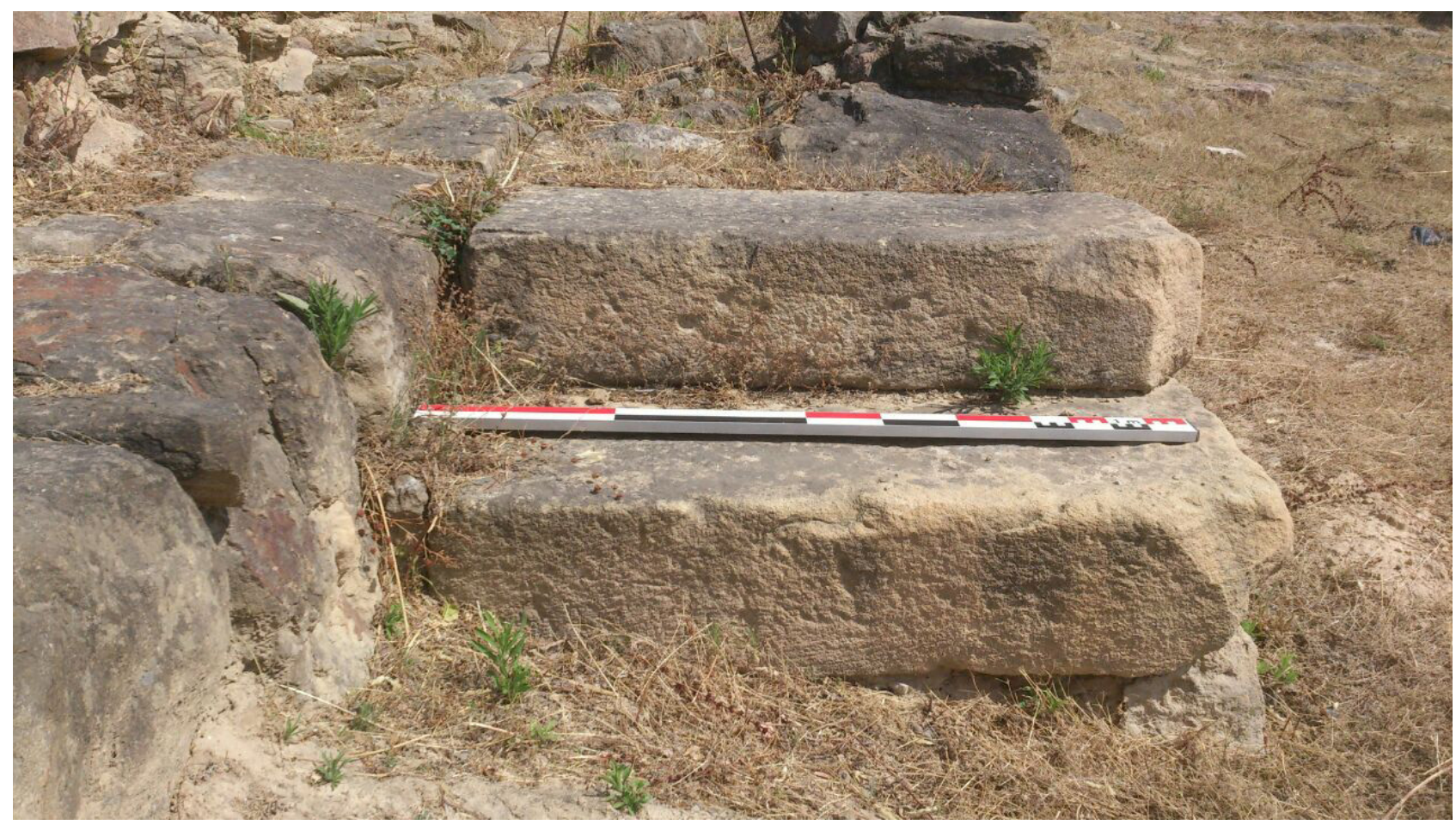

Figure 7: Staircase. By the author

The analysis of the spiked skulls, of which we can see one in Figures $8 a$ and $8 b$, would deserve in itself a paper, yet one can at least anticipate some observations, independently of the difficulty in deciphering their significance. The spiked skulls can be regarded, to some extent, as a political tool framed within the boundaries of the kinship group and the lineage, either for economic or political gain. One thing that is certain, however, is that it is an indigenous phenomenon associated purely with indigenous material evidence. The spiked skulls are an indigenous symbol that would appear to have bond to both power and the kinship relationships. It is, furthermore, plausible to regard the spiked skulls as symbols of prestige and rank within the kinship group. The latter can be inferred through a close analysis of the places in which the craniums have been found in Ullastret, chiefly the palace and the rampart. This is a differential fact with regards to the rest of the Iberic tribes of this area. It has been largely suggested that the skulls seem to appear in the archaeological record associated to swords of type La Tene II (Casas et al., 2004; Martín \& Agustí, 2006; Agustí, Codina, \& Prado, 2015). It could be argued that the spiked skulls and the swords are ethnic markers and as such will, largely, determine the maintenance of ethnic boundaries (McGuire, 1982). The concept of ethnic boundary is crucial in understanding the significance of the spiked skulls and their 
relationship to the landscape, since the alleged belt of indigenous oppida formed by Ullastret, Pontós and Peralada could be marking the ethnic boundary through which the main oppidum, Ullastret, would gain control over the flux of commerce in both directions, inland with respect to the other ethnic territories as well as towards the coastline, that is to say, the Phocaean colony of Emporion. Thus, these economic dynamics will determine the degree and intensity of the relationship between ethnic groups and these indigenous peoples and Emporion. Although it is certainly true that, in many ways, this economic interplay would not have existed without one structure of power which articulates the entire apparatus, one structure underpinned by an ideological system.

Let us now take stock of the above discussion to point out that the spiked skulls operate on a different level too, as competition provides the motivation for the elite class to maintain its power by regulating the competitiveness of landscape, natural resources, and trade, while at the same time the power reaffirms its position as a key element in society. What is of relevance to this discussion, however, is neither to whom the cranium belongs, nor whether it was an enemy, but rather its importance as an affirmation of the dominant lineage, that is, it is part of what power represents, it is a signifier of what power personifies within the system of social relations. If we examine the anatomy of power to all appearances, it may give the impression that it is fractured, at a minimum, into two differential spheres although closely interconnected: necropolis and spiked skulls. The necropolis, as we shall see further on, represents the collective dynamics of power although concentrated in a segment of the lineage through the appropriation, to a certain extent, of the cosmology; Its main characteristic is that it is assumed by the collective as somewhat natural. The coercive power is the materialisation of the latter and it is represented by the spiked skulls; Its main feature is that it is accepted by the community by force.

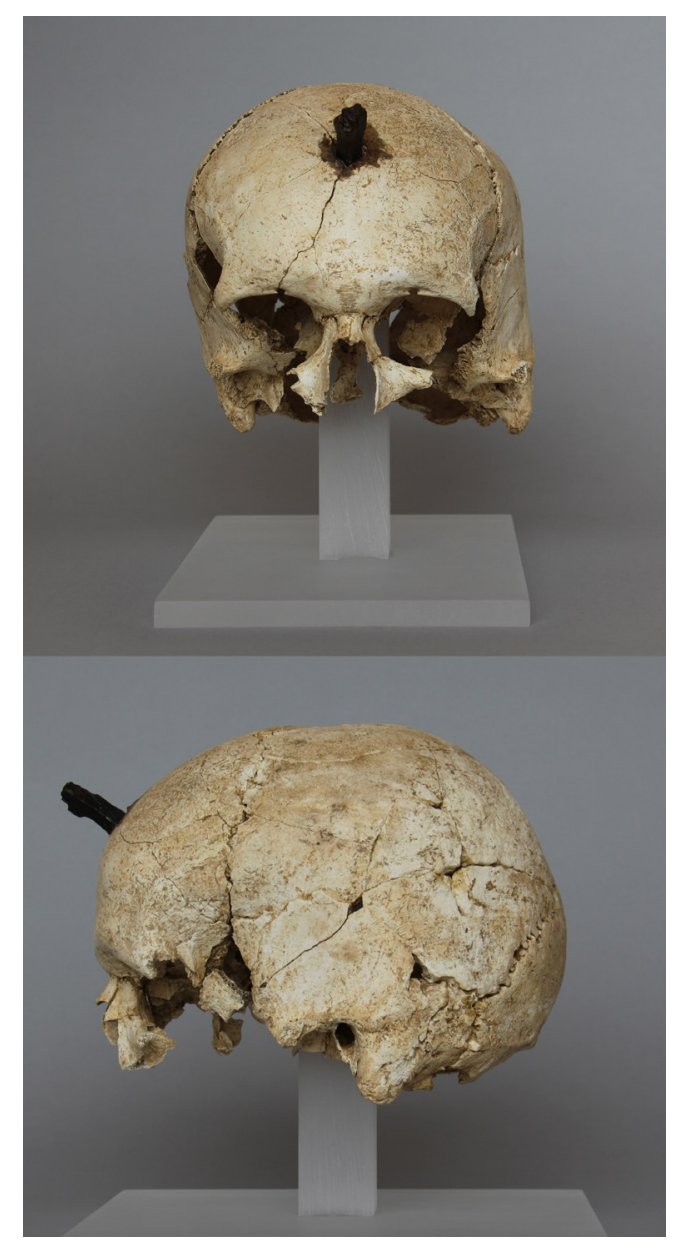

Figures 8a and 8b: Skull. Source: Archivo del Museu d'Arqueologia de Catalunya-Ullastret. 
Within this gentilic space together with the large hearth, a stone platform of large stones was found whose area was approximately one metre width by two metres length. This platform might be regarded, or at least one would suggest, is some sort of shrine or the like. Between this platform and the wall there was a slot of a few centimetres, beneath which the offering of a dog was unearthed (Casas et al., 2004). One has interpreted this offering as a reminiscence of a distant past, when these people were still living nomadically and livestock played a dominant role. This gives cause for thought, as it might be argued that this type of offering could operate as part of an ideological memory of a distant shepherding past and as such may have been subject to being seized by the leading lineages. Similarly, as underwritten by Flannery (1995), kinship bonds are grounded in a series of common beliefs shared by a given culture, such as having a common ancestor or the worship of certain deities who articulated the social cohesion of the community; thus, this forms the realm of the imaginary, underpinning the ideological system. One would propose that whereas determined lineages taking possession of the beliefs of a culture would be equivalent to exerting domination upon the tribal polity by medium of becoming intermediaries between the world of the living and the dead, by being guardians of the ideological memory or by its conversion into the mythological benchmark of the blood relatives because of its close association with the supernatural. One could say, in short, by concentrating power in the leading groups of the lineage by articulating the manipulation of the cosmology.

Let us make a closer analysis of the pertinent archaeological evidence in regard to the finds of canids in Ullastret and Mas Castellar de Pontós. The remains of dogs have appeared in Ullastret in the palace and the so-called temple B (Casas et al., 2004) and in Pontós, associated with the large domestic architectures 1 and 2 (Pons \& Colominas, 2015). The question emerges as to why buried dogs are tied in to an arena of power. The canids in Pontós have seemed linked to domestic architecture, silos, and banquets (Pons, Colominas, \& Sana, 2016). The whole skeleton of a dog was found in silo 137 contextualised along with iron utensils, imported drinking wares, and biological remains such as charred grains and livestock bones (Pons et al., 2016). One may presume that this is symbolising the close nexus between the system of belief and agriculture, whose materialisation may be the ritual meals emphasised by Pons. According to Pons numerous fragments of dog bones were found in pit 373 in association with remains of sheep, goats, cattle and pigs (Pons et al., 2016). These remains of dog were laid at the bottom of the pit and at the upper part, which is suggestive of a sheepdog that is watching over the herd and can equally be a signifier of the role played by the ideological memory in structuring the social relations. Ideological memory that, as pointed out elsewhere, could well be a vestige of the Bronze Age collective memory of this community, correlated with a system of belief which would have both survived and evolved within the kinship group politico-religious structure. Buried canids have likewise appeared in the lavish room of house number 1 of Pontós (Pons et al., 2016). Remarkably this room is, to some extent, comparable to the luxurious room of the palace in the sense that both have a large hearth, are the chief rooms, have similar dimensions, and finds of canids were unearthed. The skeletal remains of at least 3 dogs were discovered in this room coupled with a column of white Pentelic marble belonging to an altar, a considerable number of drinking vessels, and minuscule vessels with remains of aromatic herbs (Pons et al., 2016).

We should also draw attention, however, to the skulls of canids that have appeared buried in silo 134 of Mas Castellar and the so-called temple B of Ullastret, as it represents a further link in the chain of evidence. These finds prompt one to believe that the latter is suggestive of the fundamental role played by the politico-religious structure of the kinship group and its close bonds with the agrarian production, given that the canine of the silo is associated with charred seeds, whereas the other lays the emphasis on the possible existence of a certain type of building during the Iron Age that articulates the relations of power, of which temple B could well be one. As noted by Casas, Codina, Margall, Martín, Patiño and Prado (2005) the dimensions, shape, and orientation of the so-called temple $\mathrm{B}$ are completely different from temples $\mathrm{A}$ and $\mathrm{C}$, as well as its chronology, since it has been 
dated c. 350 BC. Strikingly, there was found the head of a dog, a kantharos of Iberian painted ceramic decorated with an embossed face and the skull of a canis. Handmade ceramic ware, Attic skyphos and remains of Punic Ebussitan amphorae were also unearthed. There is neither a cistern of water nor signs of an upper floor or storage facilities. The drinking vessels are, to a certain extent, pointing to a meeting place, yet not one in which a banquet could be celebrated. One has the impression that the code of beliefs would appear to be, as are the set of offerings, interlocked with the landscape, as it seems bonded to either livestock or the harvest. But there is more, the role of canids in Ullastret might have brought to the surface a possible Late Iron Age ideology feature.

Having presented the finds of canids in Ullastret and Mas Castellar, let us pass on in our enquiry to the analysis of the evidence in an attempt to unravel the significance thereof. We ought to begin by clearly stating that, if our analysis is accurate and we are dealing with a belief of the kinship group, the precise interpretation of it is beyond our scope. It is certainly plausible, however, to put forward various hypotheses in an attempt to shed some light on this most interesting theme.

It is perhaps worthy of attention the fact that the remains of dogs seem to be related to power as they have been found in or close to big dwellings linked to the elite. Of crucial importance is that the latter is precisely contextualised in the fourth and $3^{\text {rd }}$ century $\mathrm{BC}$, when, as aforementioned, the indigenous polity shifted to one grounded in the territory. It is, furthermore, remarkable that the largest amount of buried canids have emerged precisely in Mas Castellar- perhaps due to its agricultural character- where the agrarian production seems to be concentrated, which necessarily leads us to infer that there could indeed be a close relationship between agriculture and the figure of the dog.

Continuing our line of thought, it is perhaps very significant that the spatial distribution of buried canids is either bonded to an altar or agricultural tools, charred seeds, and various types of herd bones as in Pontós. One is thus tempted to reflect upon the feasibility of sacrificing dogs as a medium to propitiate a good harvest, in which case it would be the indigenous interpretation of a broadly extended belief throughout the ancient cultures. Suffice it to mention the role of dogs in the different mythologies, traditionally related to various types of religious festival, the underworld and the like (Jenkins, 1957).

It is, however, plausible to put forward another insight on the basis of the spatial analysis of the material evidence. In this regard, the spatial evidence prompts one to think that a Bronze Age belief related to pastoralism could have evolved in the course of this period towards a type of credence interconnected with harvest and the agrarian production, yet it would have kept some features of its initial facies. If this analysis is correct, the protecting role of the canids might have shifted from guarding the herds to preserving the harvest, for a belief cannot arise as a consequence of contemporaneous social relations but rather as the result of a long term social process.

The system of beliefs is intimately linked to the society in which they develop, the type of economic base, and social structures. From this viewpoint, settlement pattern and changes in the landscape, from a nomadic to a sedentary settlement model, would seem to further support the latter interpretation. One's suspicion is that the economic and technological changes from the Bronze Age to the Iron Age could have gone accompanied by a shift in the belief structure. It is suggestive, in short, of being an ideological attribute of their belief system.

One would suggest that through the above discussion, to some extent, it may be possible to make a further comparison with Rome's foundation myth owing to the set of analogies between both events and because of the etymological similarities between Canis Familiaris and Canis Lupis. It is intended to show how power is articulated through a myth, yet we ought to bear in mind that without analysing the subsequent foundational myth, that of Aeneas, the conclusions are provisional. Romulus had two mothers which represent the mechanism of power, Gaia - Rea Silvia is equated to Rhea, for the Romans Magna Mater (Rose, 2005) and the telluric forces of the woodland, Luparca, given that founding a new city would require the control of the economy. In reality, it is the same mother who expresses two different concepts, Gaia which channels the principle of fertility, abundance, the continuity of the new lineage and the she-wolf, Luparca, which represents the ancient principle of the blood fully identified with the death of Remus, the predatory face of mother earth, and the aggression 
towards sedentary settlements. In truth, the act of pouring the blood of Remus in the foundation myth has two readings which, largely, will determine the structure of the myth and the subsequent historical development of Rome. In the first place, by shedding the blood of his brother, Romulus ritually sacralised the founding of Rome given that the blood of Remus is the blood of Luparca and Gea. If that analysis is correct, Romulus elevated the status of the newly founded city at a minimum to the level of the neighbouring Etruscan cities such as Veii. Besides one is driven to suppose that the twins were found and suckled by the she-wolf for a determined reason, that is to say, thereby explicitly the circle of power remained closed since no one else could access thereof, that is, this created bonds with a natural force not accessible to the rest of the kinship group. It could be said that by maintaining inaccessible the channels of access to power and by marking out the supernatural ties of Rome through the blood of Luparca, Romulus is laying the foundations of Rome's pre-destiny.

Let us now review the north sector of the building which has been described by the bibliography as the storage area (Casas et al., 2004; Codina et al., 2012), a factor which may be considered as one of the attributes of a palace by virtue of its capacity to collect and store the tribute (Jones, 2007). This area is composed of various sectors and stands out owing to the fact that its entrance is separated from the rest of the building (Martín, 2007) and several rotary quern-stones in this sector were found together with a large number of amphorae (Casas et al., 2004). One of the most remarkable findings is a hoard of coins composed of 54 Emporitan drachms unearthed in the only room of the entire building which faces the thoroughfare - could it be the room where tribute was paid to the palace? (Campo, 2007; Codina et al., 2007). However, it is noticeable that in 1964 another assemblage of coins with exactly the same value in Emporitan drachms was found (Campo, 2007). As will be discussed below, the correspondence in the number of drachms might well correspond to an administrative payment made by Emporion, for one of the sets of coins does not appear to have been in circulation (Campo, 2007).

On the basis of this evidence, to which we ought to add that in Ullastret and Mas Castellar de Pontós lead metal bars, lead sheet and coin-shaped silver pieces have been found (Aquilué et al., 2008; Aquilué et al., 2010), has led me to raise the hypothetical existence of an economic indigenous system grounded in a dual character, that is, a non-monetised inner system and another monetised system utilised by the elite class but very much interrelated with one another. It is likely that Ullastret could have had an internal economic model without monetising, a model which would have operated only among them. One might assume that the metal bars were used by the indigenous peoples as currency. Besides a galena nodule was found at the metallurgical workshop of the palace, whose isotopic data appears to locate it within the isotopic fields of the mines in the neighbouring Mont-ras in Les Gavarres massif. It has been argued that the indigenous lead trading circuits were supplied by local minerals (Aquilué et al., 2008; Aquilué et al., 2010). However, this economic inner system seems to be far more complex, for it could have been complemented by the supply of grain to the palace, which one would suggest was a type of tribute in view of the large number of quernstones found thereof and in the large dwellings in Pontós. In this light, the enormous number of silos scattered throughout the Indiketia appears to point in the same direction. Likewise, one presupposes that the voluminous increase in the number of silos and the appearance of the large domestic architectures throughout the Catalan area is consistent with the type of social identity, seemingly tributary system grounded, articulated through the groups of power of a lineage with economic bonds with the landscape. It is fundamental to understand that this tributary taxation system would have been accepted by the peasant communities as a type of social contract, given that the improvement of the agricultural tools would have increased the living standards of those communities (Sanmartí et al., 2015). Those linkages with the territory can be inferred from the large number of animals in offerings of the palace and the possible tribute in grain accumulated in thousands of silos. This idea ought to be adequately verified by analysing the mode of production synthesised in the relational dialectics among oppida and landscape.

What is of interest to this discussion, furthermore, is that the economic outline acquires nuances of complexities, for the coins of the hoards underlies the root of a monetised administrative system, 
utilised in all likelihood in their economic activities with Emporion. This interpretation is strengthened by the fact that one of the hoards appeared contextualised together with a lead sheet with Iberian inscriptions (Aquilue et al., 2008) and the other deposit is unearthed in the palace. It is noteworthy, moreover, that the possibility of the existence of an administrative system in the Catalan area was already pointed out by Sanmartí (2004). One would add that such an economic structure, as it seems to be, could not have been sustained without a social organisation which articulated the payment of tributes, agricultural production and commerce with Emporion.

\section{The Necropolis}

The other big scenario in which the dynamics of power is negotiated is the necropolis of Ullastret. It has frequently been argued that the necropolis, as a clear landmark within the landscape, plays a determinant role in establishing the lineage territory by showing that the ancestors have lived and died there (Delgado \& Ferrer, 2007; Flannery, 1995). The necropolis of Ullastret was utilised for two centuries and is composed of 87 burials in total. It is important to bear in mind that the dataset is incomplete and my research remains ongoing, so this interpretation may need to be revised. During a conversation with Mr de Prado, current director of Ullastret, one was told that the necropolis spanned two centuries, from the middle of the $5^{\text {th }}$ century to roughly the end of the $3^{\text {rd }}$ century B.C. and that the grave goods were in the line of the graves shown at the museum. The oldest set of burials is delimited in the north by natural rock and by a ditch of 5 metres cut in the rock, and at the south-east and south-west limit of this set of burials, some animal bone offerings of deer, horse, bull and pig were found, so that one could assume that the south edge was delimited by animal offerings. The principal tomb is the so-called grave 80 (Martín, 2008).

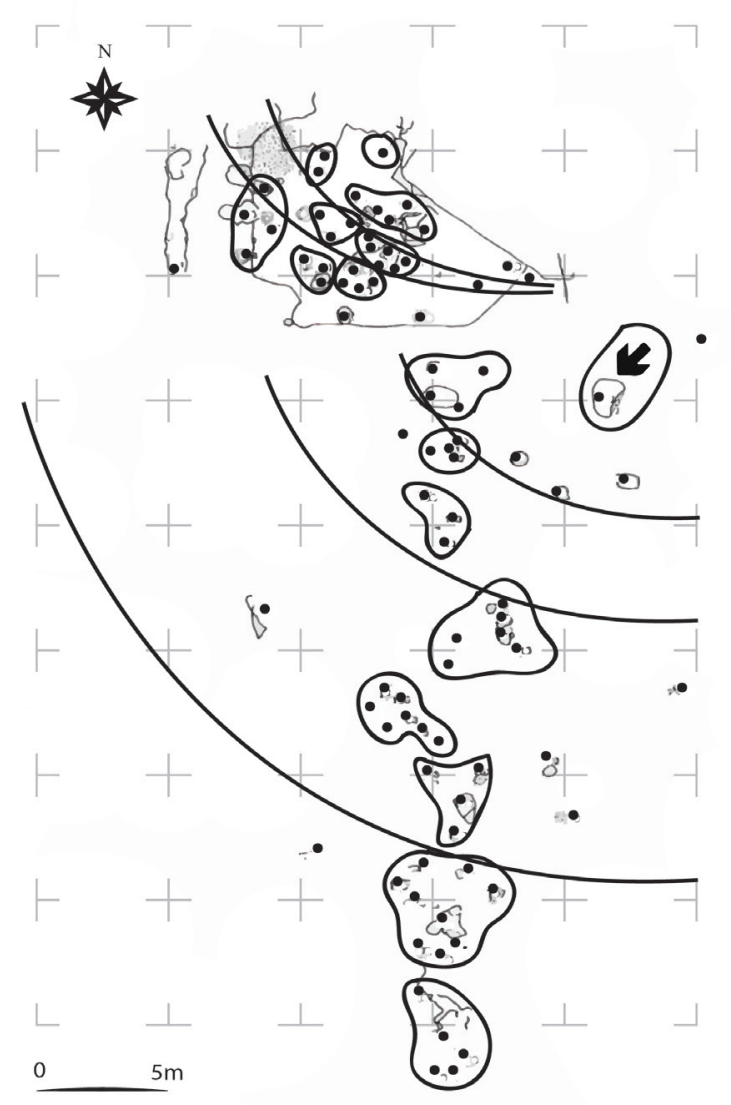

Figure 9: Necropolis. Based on the research of Martín, 2008, figure 2. 
The reduced number of graves might signify that the necropolis was reserved for the burial of the lineage which was at the apex of the social pyramid, as the type of animal bone offerings suggest. Be that as it may, the offerings would seem to indicate the sacred boundary of a power space, along with some type of social discrimination rather than a foundational role, although the germ of the idea probably existed before the founding of the necropolis. The fact that the oldest set of burials was delimited by natural rock and a ditch, the latter being, precisely, the way in which Romulus delimited the sacred boundary of Rome, gives the idea that this delimitation was made in order to mark out the founding of the lineage. One presupposes that solely the groups of power were buried in the cemetery, it hence becoming a symbol of status rather than the grave goods. As can be noted in Figure 9, the layout of the other grouping of burials shows the alluded fracture of power within a process of social change. It is composed of the focal grave and three belts of burials, correspondingly separated to secure the emergent social hierarchy, and whose most evident landmark is the enormous number of silos in the landscape. If this analysis is correct, the lineage thereby inaugurated a new social identity model grounded on the legitimacy of the power groups. It is articulated through an ideological system which linked the ideological memory, formed by the set of beliefs of the kinship group and the genealogy, to the hegemonic groups of the lineage.

Remarkably the primary grave is composed of feminine grave goods. It may be intended to reinforce the former graveyard and provide an ideological frame to support the lineage, for it may symbolise Gaia and thus this creates bonds with the territory, since the mythical ancestor could well be a feminine natural force. Indeed, during the phase of abandonment of Ullastret the oppidum gateways were sealed, a fact which denotes a clear intention to preserve the settlement and to return there. If, as we may assume, this interpretation is correct, the oppidum would be the physical representation of the aforesaid nexus of the kinship group with the landscape. Likewise, in the grave goods of tomb 32 there seems to be an association between surgical instruments and loom weights. Hence, it may aim towards the role of women as caregivers of the lineage by articulating the collective identity, perhaps one of the most precious positions within the lineage. The Rape of the Sabines might illustrate one's argument, by giving continuity to this new model of polity by assuring fecundity within the lineage. As noted by Fraschetti (2005), the Sabine women went on to live in the wealthiest Roman houses, thus giving sociological sense to the incipient Roman upper class. This interpretation suggests that the origin of both the Sabine peoples and Rome could be Etruscan, given the necessity to justify the new dynasty and the assumption that power is only legitimised by power, in this event the Etruscan peoples.

\section{Conclusion}

It is the aim of this survey, or at least an attempt, to open up new lines of enquiry with regards to dynamics of power and its interplay with social identity through various arenas such as the analysis of domestic architecture, the formation of myths and landscape. The concept of materiality is crucial in understanding the concentration of power, it marks out the historical moment, the circumstances, and accordingly the type of concentration of power and hierarchy. It does not have a fixed value and depends on the landscape and the nature of the natural resources. It is normally associated with inequalities as it can be appropriated. Furthermore, this research remains ongoing and hence some analyses are provisional and pending the publication of new data.

\section{References}

Agustí, B., Codina, F., \& Prado, G. de (2015). Exposition Publique de tetes et d'armes chez les iberes du nord. Dossiers d'Archeologie, 367, 32-37.

Aquilué, X., Castanyer, P., Santos, M., Tremoleda, J., Martín, A., Pons, E., Rovira, M. C., \& Mata, J. M. (2008). Elaboración y comercio de plata y plomo en la Emporion griega y en los hábitats 
ibéricos de su entorno. Revista d'Arqueologia de Ponent, 18, 270-291.

Aquilué, X., Armada, X., Belarte, M. C., Castanyer, P., Fairén, S., Gener, M., Gasul, P., Graells, R., Hunt, M., Martin, A., Mata, J. M., Montero-Ruiz, I., Morell, N., Pons, E., Rafel, N., Renzi, M., Rovira, M. C., Rovira, S., Santos, M., Tremoleda, J., \& Villalba, P. (2010). New approaches on the archaic trade in the north-eastern Iberian Peninsula: exploitation and circulation of lead and silver. Oxford Journal of Archaeology, 29(2), 175-202.

Belarte, M. C. (2013). El espacio doméstico y su lectura social en la protohistoria de Cataluña (s. VIIII/I a.C.). In S. Gutiérrez \& I. Grau (Eds.), De la estructura doméstica al espacio social. Lecturas arqueológicas del uso social del espacio (pp.77-94). Alicante: Publicaciones Universidad de Alicante.

Belarte, M. C., \& Valenzuela-Lamas, S. (2013). Zooarchaeological evidence for domestic rituals in the Iron Age communities of north-eastern Iberia (present-day Catalonia, sixth-second century BC). Oxford Journal of Archaeology, 32(2), 163-186.

Campo, M. (2007). Tesoro de dracmas emporitanas hallado en el Puig de Sant Andreu (Ullastret), II. Estudio de las monedas. Nvmisma, 251, 65-78.

Casas, S. Codina, F. Margall, J. Martín, A. Patiño, C., \& Prado, G. de (2005). Els temples de l'oppidum d'Ullastret. Aportacions al seu coneixement. In O. Mercadal (coord.), Món ibèric als Països Catalans. XIII Col.loqui Internacional d'Arqueologia de Puigcerdà: homenatge a Josep Barberà i Farràs (pp. 989-1002). Puigcerdà: Institut d'Estudis Ceretans.

Casas, S., Codina, F., Martín, A., Prado, G. de, \& Margall, J. (2004). La zona 14 d l'oppidum del Puig de Sant Andreu d'Ullastret. Un complex arquitectonic del segles IV i III a.C. Cypsela, 15, 265-284.

Codina, F., Gay, C., Martín, A., \& Plana, R. (2008). El jaciment Camp d'en Gou - Gorg d'en Batlle, un barri periurbà de l'oppidum d'Ullastret (Baix-Empordà). Cypsela, 17, 161-183.

Codina, F., Heinrichs, J., Lara, L., Molinas, M., Prado, G., \& Schön (2015). Étude architecturale et archéologique des citernes de l'oppidum d'Ullastret (Catalogne). In F. Olmer \& R. Roure (Eds.), Les Gaulois au fil de l'eau (pp.957-968). Montpellier: AFEAF-Editions Ausonius.

Codina, F., Martín, A., Nadal, J., Prado, G. de, \& Valenzuela, S. (2009). Étude et interprétation des dépôts fauniques sous pavement identifiés au Puig de Sant Andreu (Ullastret, Catalogne). In S. Bonnardin, C. Hamon, M. Lauwers, \& B. Quilliec (dirs.), Du matériel au spirituel: réalités archéologiques et historiques des "dépôts" de la Préhistoire à nos jours. Actes des Rencontres, 16-18 octobre 2008 (pp.133-144). Antibes: Rencontres internationales d'archéologie et d'histoire d'Antibes.

Codina, F., Martín, A., \& Prado, G. de (2007). Tesoro de dracmas emporitanas hallado en el Puig de Sant Andreu (Ullastret), I. El contexto arqueológico. Nvmisma, 251, 57-65.

Codina, F., Martín, A., \& Prado, G. de (2012). La recerca arqueològica al conjunt ibèric d'Ullastret en els darrers anys (1995-2010). Tribuna d'Arqueologia, 63-69.

Delgado, A., \& Ferrer, M. (2007). Alimentos para los muertos: mujeres, rituales funerarios e identidades coloniales, Treballs d'Arqueologia, 13, 29-68.

Flannery, K. V. (1995). Prehistoric social evolution. In C. R. Ember \& M. Ember (Eds.), Research Frontiers in Archaeology (pp. 1-26). Engle Wood Eliffs, New Jersey: Prentice- Hall.

Fraschetti, A. (2005). The foundation of Rome. Edinburgh: Edinburgh University Press.

Grau, I. (2013). Unidad doméstica, linaje y comunidad: estructura social y su espacio en el mundo ibérico (ss. VI-I a.C.). In S. Gutiérrez \& I. Grau (Eds.), De la estructura doméstica al espacio social. Lecturas arqueológicas del uso social del espacio (pp. 57-76). Alicante: Publicaciones Universidad de Alicante.

Hirth, K. (2009). Craft production, household diversification, and domestic economy in prehispanic Mesoamerica. Archaeological papers of the American Anthropological association, 19(1), 1332.

Horne, L. (1991). Reading village plans. Architecture and social change in Northeastern Iran. Expedition, 33(1), 44-52. 
Jenkins, F. (1957). The Role of the Dog in Romano-Gaulish Religion. Latomus, 16(1), 60-76 Jones, M. (2007). Feast. Why humans share food. Oxford: Oxford University Press.

Kamp, K. (2000). From village to tell: household ethnoarchaeology in Siria, Near Eastern Archaeology. Ethnoarchaeology II, 63 (2), 84-93.

Martín, A. (2007). La ciutat ibèrica d'Ullastret: del orígens a la romanització. In L. Palahi, J. M. Nolla \& D. Vivo (Eds.), De Kerunda a Gerunda: els orígens de la ciutat (pp. 71-96). Girona: Ajuntament de Girona.

Martín, A. (2008). Una tomba excepcional de la necrópolis del Puig de Serra, Serra de Daró. Annals de l'Institut d'Estudis Gironins, 49, 251-268.

Martín, A., \& Agustí, B. (2006). Actes de violència en el període iber. El cas d'Ullastret i altres poblats catalans. Cypsela, 16, 51-64.

Martín, A., \& Plana, R. (2001a). L'organitzacio de l'espai rural entorn de l'oppidum d'Ullastret: formes i dinamica del poblament. In Territori polític i territori rural durant l'edat del Ferro a la Mediterrània occidental: actes de la taula rodona celebrada a Ullastret del 25 al 27 de maig de 2000 (pp.157-176). Barcelona: Museu d'Arqueologia de Catalunya.

Martín, A., \& Plana, R. (2001b). El Nord-Est català en època ibèrica i l'entitat territorial de l'oppidum d'Ullastret. In Territori polític i territori rural durant l'edat del Ferro a la Mediterrània occidental: actes de la taula rodona celebrada a Ullastret del 25 al 27 de maig de 2000 (pp.39-52). Barcelona: Museu d'Arqueologia de Catalunya.

Martín, A., \& Plana, R. (2012). Formació i desenvolupament de l'ocupació ibèrica d'Ullastret (Baix Empordà): un centre indígena major en una zona de contacte de cultures. Cypsela, 19, 178192.

Marx, K. (1971). A contribution to the critique of political economy. London: Lawrence and Wishart.

Marx, K. (1973). Grundrisse. Foundations of the critique of political economy. Harmondsworth, Baltimore: Penguin Books.

Marx, K. (1979). Formaciones Económicas Precapitalistas. Barcelona: Crítica.

McGuire, R. H. (1982). The study of ethnicity in historical archaeology. Journal of Anthropological Archaeology, 1, 159-178.

Pearson, M. P. (1999). Food, sex and death: cosmologies in the British Iron Age with particular reference to east Yorkshire. Cambridge Archaeological Journal, 9(1), 43-69.

Pons, E., Gago, N., Fernández, M. J., \& Bouso, M., (2000). La producción agrícola y la transformación y conservación de cereales en Mas Castellar-Pontós. In C. Mata, G. Pérez (Eds.), Ibers. Agricultors, artesans i comerciants. III Reunió sobre Economia en el Món Ibèric (pp.115-123). València: Departament de Prehistòria i Arqueologia de la Universitat de València.

Pons, E., \& Colominas, L. (2015). Des silos et des rites dans le monde ibérique. Espaces de culte a Pontos. Dossiers d'Archéologie, 367, 38-43.

Pons, E., Colominas, L., \& Sana, M. (2016). Dog sacrifice at the protohistoric site of Mas Castellar (Pontos, Spain). In C. Murray (Ed.), Diversity of sacrifice. Form and function of sacrificial practices in the Ancient World and beyond (pp. 191-209). New York: State University of New York Press.

Prado, G. de (2010). La fortificación ibérica del Puig de Sant Andreu (Ullastret, Cataluña) : aspectos técnicos, formales y funcionales. In $\mathrm{H}$. Tréziny (Ed.), Grecs et indigènes de la Catalogne à la mer Noire: actes des rencontres du programme européen Ramses 2 (2006-2008) (pp. 567580). Paris: Publications du Centre Camille-Jullian.

Rose, H. J. (2005). A handbook of Greek Mythology. London: Routledge.

Sanmartí, J. (2004). From local groups to early states: the development of complexity in protohistoric Catalonia, Pyrenae, 35(1), 7-41.

Sanmartí, J,. Martín, A. \& Plana, R. (2015). Les estructures socials en els estats ibèrics de la costa de Catalunya. In M. C. Belarte, D. García \& J. Sanmartí (Eds.), Les estructures socials protohistòriques a la Gàl-lia i a Ibèria. Actes de la VII Reunió Internacional d'Arqueologia de Calafell (pp. 119-136). Barcelona: Departament de Prehistòria, Història Antiga i Arqueologia 
de la Universitat de Barcelona.

Sanmartí, J., \& Santacana, J. (2005). Els Ibers del nord. Barcelona: Rafael Dalmau.

Santley, R. S., \& Hirth, K. G. (1993). Prehispanic Domestic Units in Western Mesoamerica: Studies of the Household, Compound, and Residence. Florida: Boca Raton, CRC Press. 


\section{Panta Rei}

PANTA REI es una revista digital de investigación orientada a la Historia y otras ciencias afines. Su principal objetivo es la transmisión del conocimiento científico, dando una oportunidad también a los jóvenes investigadores que quieren abrirse camino en el estudio de las ciencias humanas y sociales. Se compone de estudios originales relacionados con la disciplina histórica así como su didáctica y difusión. Las diferentes secciones que componen la revista son: artículos de investigación, entrevistas a profesionales, recensiones de monografías de actualidad y crónicas de congresos o eventos científicos relevantes.

Todos los artículos publicados son objeto de un proceso de revisión a cargo de un mínimo de dos evaluadores, que se consideran expertos en el ámbito temático del artículo propuesto. Nuestro deseo es poder ofrecer unos contenidos rigurosos, de calidad y de interés.

EI CEPOAT (Centro de Estudios del Próximo Oriente y la Antigüedad Tardía de la Universidad de Murcia) es la institución encargada de la coordinación y gestión de la revista, desde donde anualmente se lanzará la convocatoria para aquellos que estén interesados en publicar sus trabajos, siempre relacionados con la Historia, Arqueología, Historia del Arte, Didáctica de las Ciencias Sociales, etc.

PANTA REI is a digital journal focused on History and other sciences related to it. Its main objective is the transmission of scientific knowledge by giving also an opportunity to young researchers who want to make their way in the study of human and social sciences. It is composed by original studies related to History, as well as its didactics and promotion. The different sections of this journal are: research articles, interviews to professionals, recensions on monographs about current issues and reports about congresses or relevant scientific events.

All the articles published are subject to a revision process carried out by a minimum of two reviewers who are considered to be experts in the field of the article proposed. Our wish is to offer rigorous contents with quality and being of interest to the reader.

CEPOAT (Centre of Studies of the Middle East and Late Antiquity of the University of Murcia) is the institution in charge of the coordination and management of this journal. This is the centre from where the call for papers will be launched for all the people interested in publishing their papers, always related to History, Archeology, Art History, Didactics of the Social Sciences, etc. 


\section{Normas de Publicación}

El autor se compromete a enviar trabajos originales, que no se encuentren publicados en otras revistas ni en otros idiomas. Así mismo, el mismo artículo no podrá ser presentado en otras revistas mientras dure el proceso de evaluación.

\section{Envío y presentación de originales}

Los artículos se enviarán exclusivamente a través del correo electrónico a la dirección pantarei@um.es. Los textos serán enviados en formato DOC y las imágenes en formato JPEG o TIFF, y con un tamaño mínimo de 2000 px. Éstas no aparecerán incorporadas en el texto, sino enviadas en archivo aparte y correctamente numeradas según su posición en el texto. Junto al trabajo, se rellenará y enviará un documento aparte en el que se especifiquen los datos del autor siguiendo el modelo disponible en la página Web de la revista.

Para la redacción de los trabajos se tendrá en cuenta el Manual de la American Psychological Association, en su sexta edición. La extensión máxima de los trabajos será de 30 páginas. La tipografía será Arial 11, con interlineado sencillo y sin espacio alguno entre párrafos. El texto deberá ir justificado a ambos márgenes y sin sangría en los primeros párrafos. Los márgenes serán de $2,50 \mathrm{~cm}$. En los casos en los que fuera necesario incorporar notas, éstas irán a pie de página, enumeradas consecutivamente, con tipografía Arial 10, interlineado sencillo y justificadas a ambos márgenes.

Una información más detallada se encuentra disponible en la página http://www.um.es/cepoat/ pantarei.

\section{Proceso de valoración y evaluación}

Una vez recibidos los trabajos, la Revista realizará una primera valoración. Si el trabajo enviado se ajusta a las normas de presentación propuestas, la temática es coincidente con la línea editorial de la revista y posee la calidad científica necesaria, será remitido al consejo asesor para una primera evaluación. Si no es así en este primer paso se puede rechazar directamente los documentos que incumplan claramente la línea editorial.

Será el Consejo Asesor quien indique a la revista la originalidad, relevancia, estructura, redacción, aparato bibliográfico, etc. del trabajo enviado y, para ello, se designará a dos revisores expertos externos que evaluarán cada uno de los trabajos, que pueden formar parte (o no) de este Consejo Asesor. La selección de los revisores se ajustará a la temática y características metodológicas del trabajo. El nombre y filiación de los autores serán eliminados del trabajo para su revisión, así como los revisores actuarán de manera anónima y confidencial.

Los revisores deberán rellenar un informe de evaluación que centrará su atención en aspectos tales como características formales, originalidad y novedad de los trabajos, relevancia de las propuestas y los resultados, calidad metodológica y validez científica.

Una vez terminado el proceso se decidirá la aceptación o no de los mismos y su publicación en el número que sea pertinente, así como las modificaciones susceptibles de ser realizadas para su final publicación. Dicha notificación se enviará únicamente por correo electrónico, en un plazo máximo de seis meses. 


\section{Publishing rules}

The author is committed to submit original papers not having been published in other reviews or in other languages. In this way, it is not allowed for the same paper to be presented in other reviews during the evaluation process.

\section{Submission and presentation of originals}

The articles will be exclusively submitted by email to pantarei@um.es. The texts will be submitted in DOC format and the images in JPEG or TIFF format, and with a minimum size of 2000 px. Images will not be integrated in the text but sent in another file and properly numbered according to their position in the text. Attached to the paper, a document will be filled out and sent where the author's data will be specified following the model available on the website.

The sixth edition of the Manual of the American Psychological Association will be taken into account for the writing of the papers. The length of the papers must not exceed 30 pages. Typography will be Arial 11 , with simple line spacing and no space between paragraphs. The text must be justified on both margins without indentation in the first paragraphs. Margins size will be $2.50 \mathrm{~cm}$. Where it could be necessary the incorporation of notes, they will be at the bottom of the page, consecutively numbered with typography Arial 10, simple line spacing and justified on both margins.

More detailed information is available on the website: http://www.um.es/cepoat/pantarei.

\section{Examination and assessment process}

The Journal will submit the papers to a first examination once received. If the paper follows the presentation guidelines, the subject agrees with the editorial line of this journal, and possess the scientific quality required, it will be sent to the advisory council for a first assessment. If not, the documents which clearly fail to complete the editorial line may be rejected straightaway in this first step.

The Advisory Council will indicate the originality, relevance, structure, writing, bibliography, etc. of the text to the journal; for this purpose, two outside experts will be designated to review the papers; these experts can be (or not) part of this Advisory Council. The selection of the experts will adjust to the subject and methodological characteristics of the paper. Name and affiliation of the author will be eliminated from the text for its review, in this way experts will act anonymously and confidentially.

The experts will fill out an assessment report which will focus on aspects such as formal characteristics, originality and novelty of the papers, relevance and results of the proposal, methodological quality and scientific validity.

Once the process is finished, the acceptance or not of the papers and its publication in the corresponding edition will be decided, as well as the modifications that may be done for its final publication. This notification will be sent by email within 6 months maximum. 


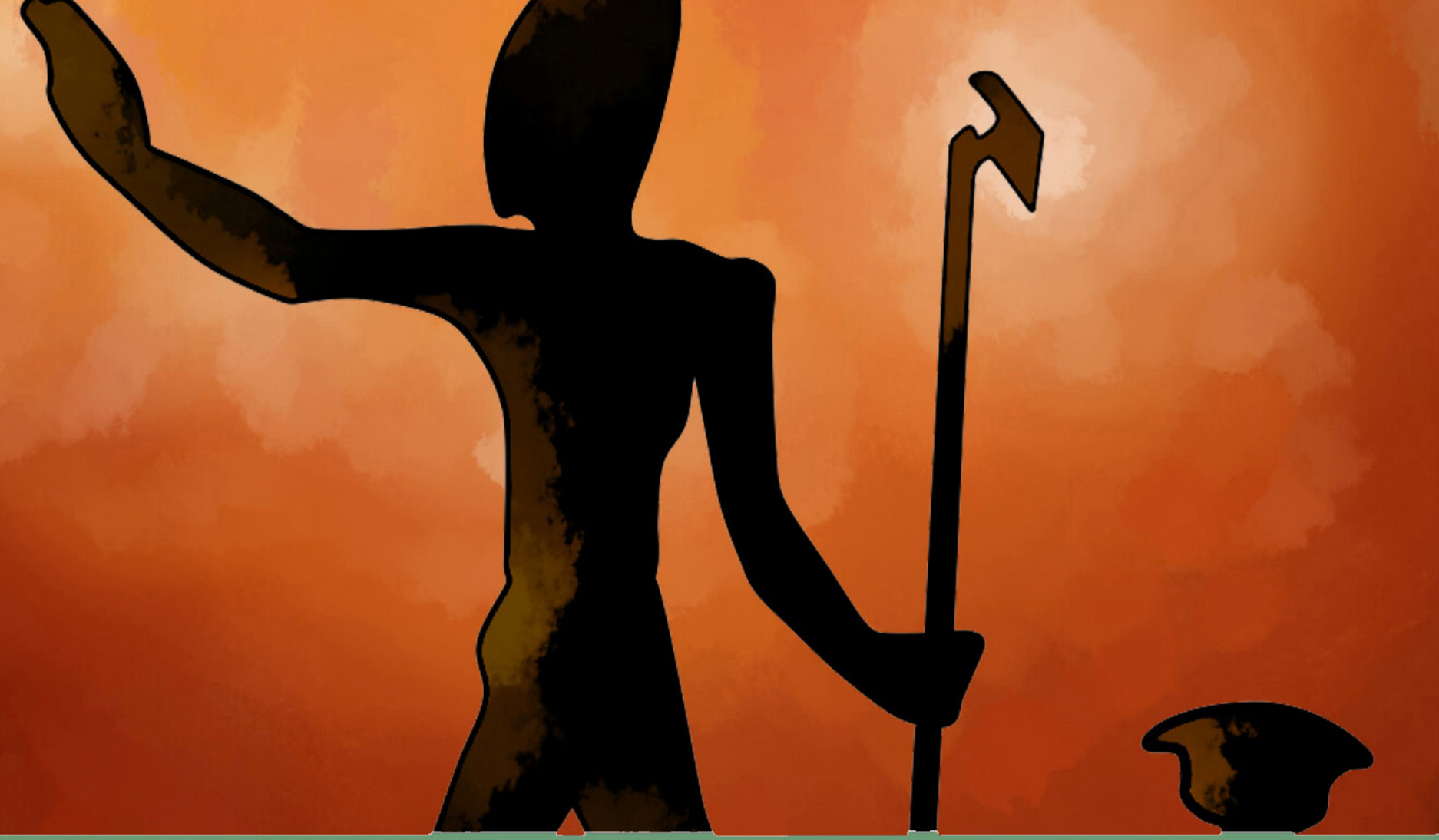

\section{cepot}

UNIVERSIDADD DE MURCIA

centro de estudios del

próximo oriente y la

antigüedad tardía 